\title{
Deciphering c-MYC-regulated genes in two distinct tissues
}

\author{
Samuel C Robson ${ }^{1}$, Lesley Ward ${ }^{2}$, Helen Brown ${ }^{2}$, Heather Turner ${ }^{3}$, Ewan Hunter ${ }^{4}$, Stella Pelengaris ${ }^{5 \dagger}$ and \\ Michael Khan ${ }^{6 *}$
}

\begin{abstract}
Background: The transcription factor MYC is a critical regulator of diverse cellular processes, including both replication and apoptosis. Differences in MYC-regulated gene expression responsible for such opposing outcomes in vivo remain obscure. To address this we have examined time-dependent changes in global gene expression in two transgenic mouse models in which MYC activation, in either skin suprabasal keratinocytes or pancreatic islet $\beta$ cells, promotes tissue expansion or involution, respectively.

Results: Consistent with observed phenotypes, expression of cell cycle genes is increased in both models (albeit enriched in $\beta$-cells), as are those involved in cell growth and metabolism, while expression of genes involved in cell differentiation is down-regulated. However, in $\beta$-cells, which unlike suprabasal keratinocytes undergo prominent apoptosis from 24 hours, there is up-regulation of genes associated with DNA-damage response and intrinsic apoptotic pathways, including Atr, Arf, Bax and Cycs. In striking contrast, this is not the case for suprabasal keratinocytes, where pro-apoptotic genes such as Noxa are down-regulated and key anti-apoptotic pathways (such as Igf1-Akt) and those promoting angiogenesis are up-regulated. Moreover, dramatic up-regulation of steroid hormone-regulated Kallikrein serine protease family members in suprabasal keratinocytes alone could further enhance local Igf1 actions, such as through proteolysis of Igf1 binding proteins.

Conclusions: Activation of MYC causes cell growth, loss of differentiation and cell cycle entry in both $\beta$-cells and suprabasal keratinocytes in vivo. Apoptosis, which is confined to $\beta$-cells, may involve a combination of a DNAdamage response and downstream activation of pro-apoptotic signalling pathways, including Cdc2a and p19Arf/ p53, and downstream targets. Conversely, avoidance of apoptosis in suprabasal keratinocytes may result primarily from the activation of key anti-apoptotic signalling pathways, particularly lgf1-Akt, and induction of an angiogenic response, though intrinsic resistance to induction of p19 Arf by MYC in suprabasal keratinocytes may contribute.
\end{abstract}

\section{Background}

The $c-M Y C$ proto-oncogene encodes a transcription factor, $\mathrm{c}-\mathrm{MYC}$ (MYC), which regulates the expression of cellular targets involved in a wide range of diverse cellular functions, including cell growth, proliferation, loss of cell-cell contact, loss of differentiation and angiogenesis [1-8]. While the predominant role of physiological MYC in most tissues is to promote G1/S transition in the cell cycle (and thereby proliferation) $[1,9,10]$ and inhibit differentiation [11-13], deregulated MYC (oncogenic) can

\footnotetext{
* Correspondence: Michael.Khan@warwick.ac.uk

† Contributed equally

${ }^{6}$ Biomedical Research Institute, Department of Biological Sciences, University of Warwick, CV4 7AL, UK

Full list of author information is available at the end of the article
}

lead to uncontrolled proliferation and tumour growth [3]. Paradoxically though, MYC is able to act as its own tumour suppressor, as deregulated MYC activity can also promote apoptosis (both in vitro [14-16] and in vivo [17]) and senescence $[18,19]$. See [20] for a recent review of the MYC field. Such linkage between seemingly opposing functions - proliferation and apoptosis - is also found in other cell-cycle-associated genes, such as E2f, E1a and c-Fos [21].

The mechanisms by which MYC elicits the vast host of biological responses for which it appears to be responsible are not yet fully understood. Currently, around 1,700 genes have been classified as putative MYC targets $[22,23]$ using methods such as serial analysis of gene expression (SAGE) [24], DNA microarrays
C Biomed Central

ㄷ 2011 Robson et al; licensee BioMed Central Ltd. This is an Open Access article distributed under the terms of the Creative Commons Attribution License (http://creativecommons.org/licenses/by/2.0), which permits unrestricted use, distribution, and reproduction in any medium, provided the original work is properly cited. 
[3] and subtractive hybridization [25]. It has been hypothesized that MYC may have the potential to regulate up to $15 \%$ of the entire genome [26], leading to it being described as a 'master regulator' of gene expression.

Regulatable transgenic mouse models have allowed controlled activation of a modified MYC-containing chimaeric transcription factor $\left(\mathrm{MYC}-\mathrm{ER}^{\mathrm{TAM}}\right)$ in distinct cell populations in adult mice, such as the pancreatic islet $\beta$ cells [27] and suprabasal keratinocytes (SBK) of skin epidermis [28]. Our previous work has shown that continuous activation of MYC-ER ${ }^{\text {TAM }}$ in these diverse tissues exposes the dual potential of MYC to activate pathways involved in cell replication and cell death under differing environmental conditions. In suprabasal epidermis, MYC promotes entry of post-mitotic keratinocytes into the cell cycle, concomitant with loss of differentiation and increased vascularization leading to formation of precancerous papillomas [28]. In contrast, although MYC promotes rapid cell cycle entry of pancreatic $\beta$-cells, these cells quickly proceed to undergo apoptosis leading to severe cell depletion and diabetes [27]. This indicates a crucial role for tissue context and the surrounding microenvironment in determining cell fate.

The divergence of MYC-induced phenotypes between these two tissues has enabled us to compare MYC-regulated gene expression patterns over a time course of MYC-ER ${ }^{\mathrm{TAM}}$ activation, by employing high-throughput transcriptome analysis using microarrays. Comparison of the transcriptional response between the two tissues identified potential signalling pathways which may promote apoptosis of $\beta$-cells and prevent apoptosis in SBK; the DNA-damage response pathway, and the Insulin-like growth factor 1 (Igf1) signalling pathway, respectively. In addition, up-regulation of angiogenesis-related genes and of those encoding members of the steroid hormone-regulated Kallikrein serine protease family was found in SBK but not in $\beta$-cells. Kallikreins may increase availability and action of Igf1 through proteolysis of Igf1 binding proteins. Together with angiogenesis, Kallikreins may provide a local tissue-specific regulatory mechanism for determining ultimate MYC function in vivo.

\section{Results and Discussion}

Activation of MYC-ER ${ }^{\text {TAM }}$ mediates transcription of genes involved in a wide range of cellular functions

Time courses were set up following activation of MYC in $\beta$-cells (pancreas) and SBK (skin) via administration of 4-hydroxytamoxifen (4OHT) for $4 \mathrm{hrs}, 8 \mathrm{hrs}$, $16 \mathrm{hrs}$ and 32 hrs as described (Methods). Vehicle-treated samples acted as direct time point controls for 4OHT-treated samples. Laser capture microdissection (LCM) was utilized to allow isolation of pancreatic islet tissue. Significant gene expression changes for the main experimental conditions (4OHT treatment, tissue type and time point following initial treatment) and their interactions, as well as information on the effects of further covariates such as batch effects and RNA quality, were identified using a custom $\mathrm{R}$ package, Envisage (available on request).

Analysis of gene expression for 12,349 curated probe sets (Methods) identified 6,633 unique genes as being significantly altered following activation of MYC with a false discovery rate of 5\%. 1,615 genes showed significant effects for the joint effects of $4 \mathrm{OHT}$ treatment, time and tissue type; 2,015 genes showed significant effects for the interaction between 4OHT treatment and tissue type; 2,221 genes showed significant effects for the interaction between $4 \mathrm{OHT}$ treatment and time; and 1,843 genes showed significant effects for the main effect of $4 \mathrm{OHT}$ treatment only. Of the MYC-responsive genes, the expression levels of 1,199 were altered greater than 2-fold (up- or down-regulated) after only 4 hours of $4 \mathrm{OHT}$ treatment for the pancreatic $\beta$-cells, while only 530 were similarly affected for SBK. However, at 8 hours following initial $4 \mathrm{OHT}$ treatment, the expression levels of 1,905 and 1,882 were altered greater than 2fold for the pancreas and the skin respectively (Figure 1A). This suggests a more prominent initial response to MYC in $\beta$-cells compared to SBKs.

Gene ontology (GO) enrichment analysis using the DAVID functional annotation tool [29] identified enrichment of genes involved in myriad cellular functions following activation of MYC. The majority of MYCresponsive genes were involved in metabolic, transcriptional, transportational and signal transduction pathways (Figure 1B; green bars). Genes involved in post-transcriptional modification (e.g. RNA processing, RNA splicing) and post-translational modification (e.g. protein catabolic process, protein folding, protein localization and ubiquitin-dependent catabolic process) were also significantly enriched. Similarly, a significant enrichment of genes relating to ribosome biogenesis was detected, suggestive of MYC's recently elucidated role as a regulator of ribosome biogenesis and protein synthesis [30]. As expected given the role of MYC in proliferation, genes involved in cell cycle progression were amongst the most significantly enriched $\left(\mathrm{p}=1.21 \times 10^{-17}\right)$. Genes involved in apoptosis and DNA-damage checkpoint pathways were also enriched $\left(\mathrm{p}=7.81 \times 10^{-3}\right.$ and $\mathrm{p}=5.07 \times 10^{-5}$ respectively), along with genes involved in related functions such as cellular response to stress $\left(\mathrm{p}=1.56 \times 10^{-8}\right)$ and cytoskeleton organisation $\left(\mathrm{p}=9.12 \times 10^{-5}\right)$.

Enrichment of GO terms for MYC-responsive genes showing early changes in expression ( $\geq 2$-fold change within the first 8 hours of MYC activation) for the pancreas (Figure 1B; blue bars) and skin (Figure 1B; red bars) identified similar numbers for both tissues, with 


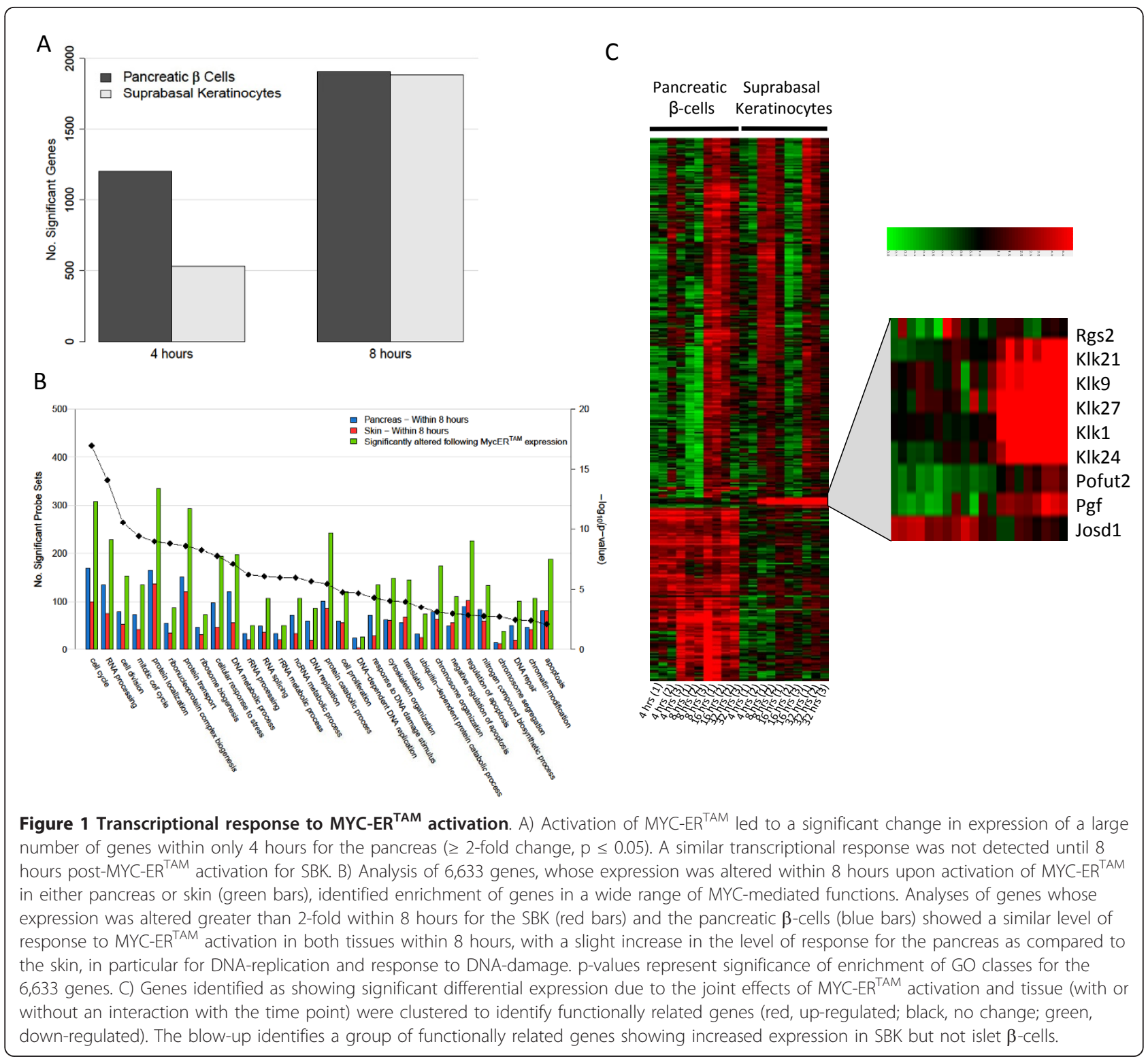

the exception of genes relating to DNA-damage and DNA replication, where a larger number of genes are detected for the pancreas than for the skin. These results indicate that whilst expression of genes relating to multiple cellular functions is common to both tissues, expression of genes involved in DNA-damage and replication is more specific to the $\beta$-cells.

\section{Expression of putative MYC target genes following MYC- $\mathrm{ER}^{\mathrm{TAM}}$ activation}

The MYC Target Gene Database [31] currently identifies 1,697 genes as putative MYC targets [22]. Of these, $13.4 \%$ and $19.2 \%$ were found to be both MYC-responsive and show a 2 -fold change in expression in the skin and pancreas respectively within 8 hours (Additional file
1, Table S1). The predominant role for these genes was in DNA replication, biosynthesis, metabolism, cell cycle, cell division and other related functions. Cellular functions relating to apoptosis and cell death were also highly enriched, although to a lesser degree than those relating to cellular proliferation. These data suggest that activation of the MYC-ER ${ }^{\mathrm{TAM}}$ protein in vivo leads to a rapid change in the expression of a large number of putative MYC targets. However, known target genes represent only a small fraction of detected MYC-responsive genes, indicating that the majority of these observed expression changes may be downstream of direct MYCinduced transcription.

To identify the level of overlap between the genes classed as significantly altered in this study and those 
identified in previous analyses, we utilised the Gene Set Enrichment Analysis (GSEA) program developed by the Broad Institute [32]. This allowed us to identify gene sets in which significant differentially expressed genes are enriched. Gene sets were taken from the Molecular Signatures Database (MSigDB), as well as from additional published datasets. Additional file 1, Table S7 and Additional file 1, Table S8 show the results from GSEA (FDR $<0.01)$ for the genes showing significant expression at the early time points ( 4 hours and 8 hours) for the pancreas and skin, respectively. These results indicate a clear enrichment in the pancreas of genes annotated as being related to MYC function from previous publications, including MYC target genes from the MYC Target Gene Database [22], genes indicative of a MYC-induced oncogenic signature from Blid et al. [33] and genes up-regulated in the studies of Coller et al., Schumacher et al., Yu et al., and Lee et al. [3,34-36]. Similarly, down-regulated genes showed enrichment with down-regulated genes from the study of $\mathrm{Yu}$ et al. [36]. In comparison, genes up-regulated in the skin are enriched for genes also found to be up-regulated in the studies of Coller et al., Yu et al. and Zeller et al. $[3,22,36]$, while MYC target genes from the MYC Target Gene Database [22], genes indicative of a MYC-induced oncogenic signature from Blid et al. [33] were enriched with an FDR value $<0.017$. This suggests that the gene expression signature identified in both the pancreas and skin is indicative of changes in expression related to MYC function.

\section{Cell cycle response following MYC activation}

One of the key functions of the MYC onco-protein is promotion of cell cycle progression, particularly G1/S phase transition $[1,2,37]$. Activation of MYC in suprabasal keratinocytes $(\mathrm{SBK})$ and pancreatic $\beta$-cells has been previously shown to initiate G1/S transition in target cells $[27,28,38]$, and this was seen through immunohistological staining with anti-Ki67 antibodies (Figure 2A), as well as in the response detected in genes relating to cell cycle progression by gene ontology classification (Figure $1 \mathrm{~B}$ and Additional file 1 Table S2). A subset of some interesting genes from this list is shown in Table 1.

Activation of MYC in the $\beta$-cells resulted in a change in expression of 213 cell cycle- and proliferation-related genes within 8 hours of MYC activation, with 116 genes up-regulated and 101 genes down-regulated (Additional file 1, Table S2). Pcna, a MYC target gene associated with the cell cycle, was expressed in both pancreatic $\beta$ cells and SBK throughout most of the time-course, with $C d c 25 a$ expressed only in the former. In $\beta$-cells, cyclin genes Ccnd1, Ccnd2 and Ccne2, whose products are necessary for $G_{1} / S$-phase transition in the cell cycle, were up-regulated within 4 hours of MYC activation.
Cyclin genes Ccna2, Ccnb1 and Ccne1, whose products are involved in later $G_{1} / S$-phase and $G_{2} / M$-phase cell cycle events, were up-regulated greater than 3 -fold subsequently at 8 hours (Table 1 and Figure 2C).

Activation of MYC in the SBK resulted in a less prominent cell cycle response compared to $\beta$-cells, with a change in expression of 144 cell cycle- and proliferation-related transcripts within 8 hours of MYC activation - 73 genes up-regulated and 74 genes downregulated (Additional file 1, Table S2). Of $\mathrm{G}_{1} / \mathrm{S}$-phase cell cycle genes, $C c n d 2$ and $C c n d 3$ showed a $\geq 2$-fold increase in expression at 8 hours. In contrast to $\beta$-cells, later cell cycle genes such as Ccna 2 and Ccne 2 were either down-regulated or unchanged in SBK. Interestingly, the $C c n b 1$ gene whose product, cyclin B1, is involved predominantly in later cell cycle events (G2/M transition), was down-regulated 2-fold in SBK early in the time-course. Cyclin B1 interacts with Cdc2a (Cdk1) to form the mitotic initiation complex, which was also down-regulated by $\sim 2$-fold at 4 hrs in epidermis. This contrasts with $\beta$-cells, in which both $C c n b 1$ and $C d c 2 a$ showed significant up-regulation. Although speculation here, these findings may suggest SBK are able to enter the G1/S phase of the cell cycle, which is a known function of MYC, but not progress through the G2/M phase. Interestingly, it was previously shown that over-expression of MYC causes a P53-dependent G2 arrest in normal fibroblasts [39]. Such cells may then be enforced by MYC to reinitiate DNA replication, resulting in aneuploidy.

Of these cell cycle-related genes, Ccna2 [40] and Ccnd1 $[41,42]$ have been previously designated as putative MYC targets through high-throughput screening, and Ccnb1 [43] and Ccnd2 [44-46] have been previously confirmed as direct transcriptional targets of MYC through the use of chromatin Immunoprecipitation (ChIP) analysis. The cyclin D2-related kinase Cdk4, also a previously characterized direct MYC target [47], showed increased expression after 4 hours of MYC activation in the pancreas, with a 6-fold increase detected subsequently at 16 hours. $C d k 4$ was also found to be highly up-regulated at 8 hours in the skin, with a fold change of almost 12 (Table 1). No significant change was detected for the cyclin E-associated CDK gene Cdk2 in either the skin or the pancreas, However $C d k 7$, which has a role in both activating cyclin complexes and regulating transcription, was up-regulated at 8 hours in the skin.

Down-regulation of another known MYC target gene, the cyclin dependent kinase (CDK) inhibitor $C d k n 1 b$ (p27 ${ }^{\text {Kip1 }}$ ), which inhibits $G_{1} / S$-phase transition by association with the cyclin E-Cdk2 complex [48], was detected for both the skin and the pancreas. Also, the expression of $C k s 2$, a MYC target gene whose product is 


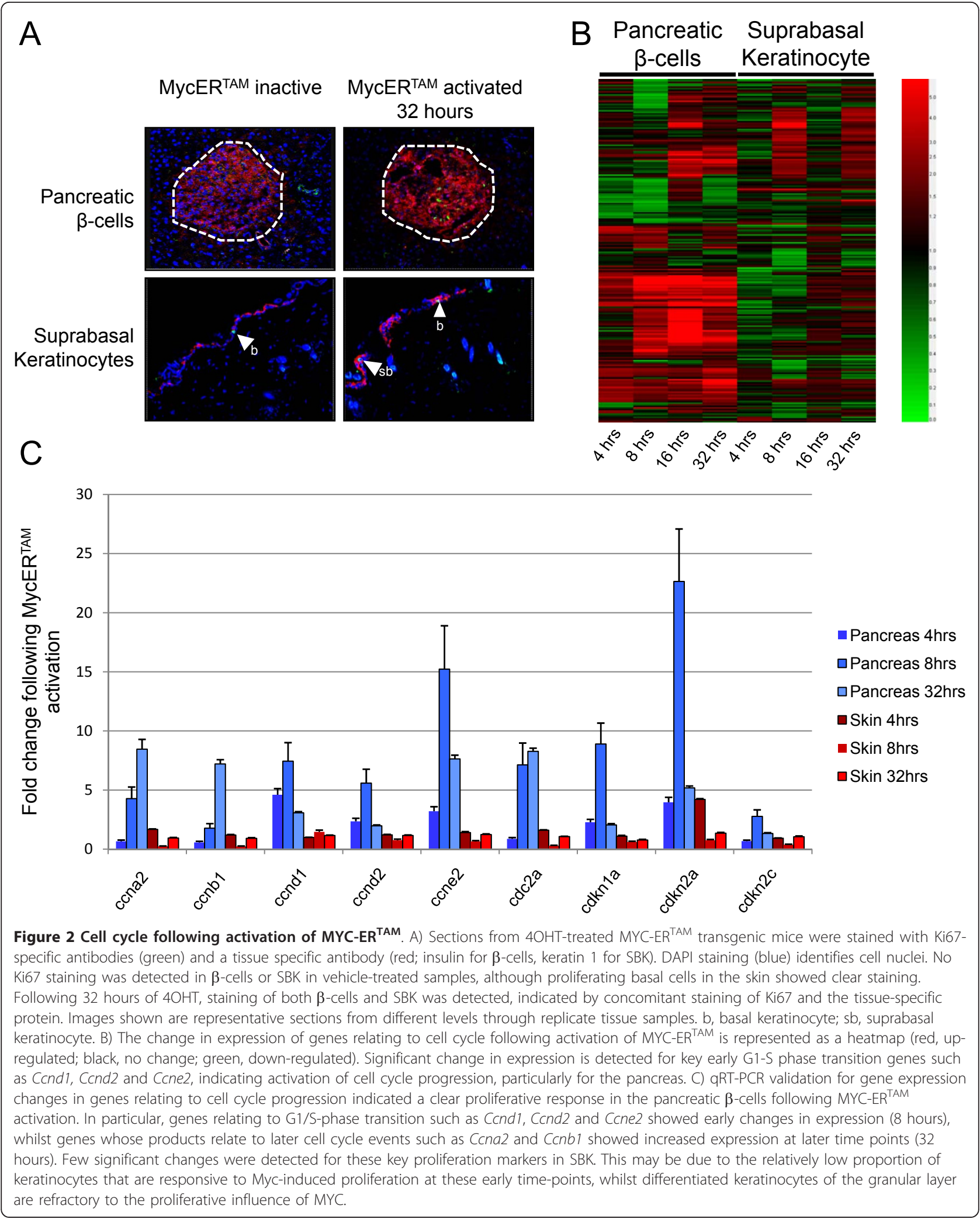


Table 1 Cell cycle and cell growth genes responsive to MYC-ER ${ }^{\text {TAM }}$ activation

\begin{tabular}{lllllllll}
\hline & & \multicolumn{5}{c}{ Pancreatic $\beta$-Cells } & \multicolumn{5}{c}{ Suprabasal Keratinocytes } \\
\cline { 2 - 7 } Gene Symbol & RefSeq & 4 Hours 8 Hours & 16 Hours & 32 Hours & 4 Hours 8 Hours & 16 Hours & 32 Hours & Myc-response p-value \\
\hline
\end{tabular}

\section{Cell Cycle}

\begin{tabular}{|c|c|c|c|c|c|c|c|c|c|c|}
\hline ccna2 & $\times 75483$ & 0.96 & $4.52^{* *}$ & $10.49^{* *}$ & $3.25^{* *}$ & 0.81 & 0.67 & 1.39 & 0.97 & 2.05E-02 \\
\hline ccna2 & X75483 & $0.55^{* *}$ & $1.33^{*}$ & $12.39 * *$ & $3.47^{* *}$ & $0.63^{* *}$ & $0.71^{*}$ & 0.99 & 1.05 & $1.12 \mathrm{E}-02$ \\
\hline ccnb1 & NM_007629 & 1.02 & 0.90 & $2.38^{* *}$ & 1.13 & $0.48^{* *}$ & 1.03 & 1.01 & $0.58^{* *}$ & $9.74 \mathrm{E}-03$ \\
\hline ccnb1 & NM_007629 & 1.06 & $2.85^{* *}$ & $8.15^{* *}$ & $3.62^{* *}$ & 0.60 & $0.46^{*}$ & 1.39 & 0.61 & $3.73 \mathrm{E}-02$ \\
\hline ccnd 1 & NM_007631 & $1.86^{* *}$ & $2.09^{* *}$ & 0.88 & 1.45 & 1.13 & 1.31 & $1.79^{*}$ & 1.04 & 4.55E-02 \\
\hline ccnd1 & NM_007631 & 1.69 & 2.38 & 1.41 & $2.27^{*}$ & 1.05 & 1.33 & 1.72 & 1.26 & 2.24E-02 \\
\hline ccnd 1 & NM_007631 & $3.41^{* *}$ & $2.74^{*}$ & $2.03^{*}$ & 2.05 & 1.35 & 0.99 & 1.54 & 1.81 & 2.23E-02 \\
\hline ccnd2 & NM_009829 & $1.63^{*}$ & $0.61^{*}$ & $2.28^{* *}$ & $2.95^{* *}$ & 1.37 & 1.46 & 0.94 & 1.40 & $2.62 \mathrm{E}-02$ \\
\hline ccnd2 & NM_009829 & 1.82 & 1.03 & 1.22 & $1.90^{*}$ & 0.83 & 1.33 & 0.97 & 1.78 & $1.48 \mathrm{E}-02$ \\
\hline cend 2 & NM_009829 & $2.06^{* *}$ & $2.04^{* *}$ & 1.27 & $2.30^{* *}$ & 0.90 & 0.84 & 1.29 & 0.84 & $1.21 \mathrm{E}-02$ \\
\hline ccnd2 & AK007904 & $1.99 * *$ & $0.64^{*}$ & $1.88^{* *}$ & $2.62^{* *}$ & $1.66^{*}$ & $2.57^{* *}$ & 1.00 & $2.13^{* *}$ & $1.28 \mathrm{E}-03$ \\
\hline ccnd2 & NM_009829 & $2.09^{*}$ & 1.00 & 1.06 & $2.01^{*}$ & 1.26 & 0.96 & 1.12 & 1.51 & $2.38 \mathrm{E}-02$ \\
\hline ccnd3 & NM_007632 & $1.26^{*}$ & 0.84 & $1.54^{* *}$ & 1.20 & $0.81^{*}$ & $2.58^{* *}$ & 0.84 & $3.33^{* *}$ & 8.71E-04 \\
\hline ccnel & NM_007633 & $1.82^{* *}$ & $3.37^{* *}$ & $7.02^{* *}$ & $1.71^{*}$ & 0.94 & 1.35 & 1.15 & $1.82^{* *}$ & 2.52E-02 \\
\hline ccne1 & BB293079 & $1.83^{* *}$ & $6.68^{* *}$ & $1.87^{* *}$ & $2.04^{* *}$ & 0.85 & $1.50^{*}$ & 1.16 & 1.29 & $1.02 \mathrm{E}-02$ \\
\hline ccne2 & AF091432 & $2.62^{* *}$ & $5.86^{* *}$ & $5.92^{* *}$ & $7.86^{* *}$ & 1.74 & 1.11 & 1.42 & 1.39 & 1.45E-02 \\
\hline cdc2a & NM_007659 & 0.95 & $2.91^{* *}$ & $11.93^{* *}$ & $3.35^{* *}$ & $0.51^{*}$ & 1.17 & 0.89 & 1.12 & 4.33E-02 \\
\hline $\operatorname{cdc} 25 a$ & C76119 & $2.71^{* *}$ & $2.23 * *$ & $2.09^{* *}$ & $3.90^{* *}$ & 1.11 & $0.46^{* *}$ & 1.07 & 0.78 & $1.84 \mathrm{E}-03$ \\
\hline $\operatorname{cdc} 25 a$ & C76119 & $2.17^{* *}$ & $1.73^{*}$ & $2.03^{* *}$ & $2.10^{* *}$ & 1.02 & 1.14 & 1.1 & 1.21 & $2.45 \mathrm{E}-02$ \\
\hline cdk4 & NM_009870 & 1.16 & 0.92 & $8.41^{* *}$ & 1.11 & 1.32 & $12.27^{* *}$ & 0.74 & 1.62 & 2.70E-02 \\
\hline cdk4 & NM_009870 & 1.21 & 0.74 & $5.31^{* *}$ & 1.5 & 1.23 & $11.30^{* *}$ & 0.92 & 1.48 & 3.31E-02 \\
\hline cdk4 & NM_009870 & 1.20 & 0.88 & $5.03^{* *}$ & 1.3 & 1.37 & $11.17^{* *}$ & 0.72 & 1.37 & 3.45E-02 \\
\hline cdk7 & U11822 & $0.63^{*}$ & 0.77 & $3.69^{* *}$ & $3.45^{* *}$ & 0.82 & $2.12^{* *}$ & 1.09 & $1.59^{*}$ & 1.37E-02 \\
\hline cks2 & NM_025415 & 0.92 & $3.03^{* *}$ & $10.08^{* *}$ & $4.80^{* *}$ & $0.51^{* *}$ & 0.76 & 1.27 & 0.71 & 4.37E-03 \\
\hline cks2 & NM_025415 & 0.98 & $2.33^{* *}$ & $8.92^{* *}$ & $2.34^{* *}$ & $0.63^{*}$ & 0.92 & 0.93 & 1.32 & $1.18 \mathrm{E}-02$ \\
\hline pena & BC010343 & 1 & $2.44^{* *}$ & $17.91 * *$ & $4.75^{* *}$ & 1.32 & $3.24^{* *}$ & 0.76 & $3.08^{* *}$ & $3.38 \mathrm{E}-02$ \\
\hline pent & NM_008787 & $2.70^{* *}$ & $3.79 * *$ & $5.22^{* *}$ & $4.18^{* *}$ & 1.14 & $1.89^{* *}$ & 1.10 & $1.82^{* *}$ & 5.43E-06 \\
\hline
\end{tabular}

\section{Cell Cycle Arrest}

\begin{tabular}{lllllllllll}
\hline cdkn1a & AK007630 & $1.57^{* *}$ & $2.05^{* *}$ & $1.71^{* *}$ & 1.24 & 0.96 & $1.44^{*}$ & 0.99 & 0.90 & $5.01 \mathrm{E}-03$ \\
cdkn1b & NM_009875 & 1.03 & $0.19^{* *}$ & 0.71 & 0.95 & $0.23^{* *}$ & $0.42^{*}$ & $0.48^{*}$ & 0.89 & $1.02 \mathrm{E}-02$ \\
cdkn2a & NM_009877 & $2.17^{* *}$ & $1.79^{* *}$ & $1.57^{* *}$ & $2.61^{* *}$ & 1.21 & 1.07 & 1.07 & 0.87 & $8.43 \mathrm{E}-03$ \\
cdkn2C & BC027026 & $0.32^{* *}$ & 1.18 & $5.62^{* *}$ & $0.59^{*}$ & 0.85 & 1.28 & 0.87 & $1.60^{*}$ & $9.38 \mathrm{E}-03$ \\
gadd45g & AK007410 & $0.59^{*}$ & $0.41^{* *}$ & $1.88^{* *}$ & $0.59^{* *}$ & $4.07^{* *}$ & $5.16^{* *}$ & $3.39^{* *}$ & $2.78^{* *}$ & $5.95 \mathrm{E}-03$ \\
gas6 & NM_019521 & $0.60^{* *}$ & $0.73^{* *}$ & 1.02 & 0.90 & $1.39^{* *}$ & $2.61^{* *}$ & $1.43^{* *}$ & $5.62^{* *}$ & $2.31 \mathrm{E}-02$ \\
ing3 & BB298005 & 0.90 & 1.12 & 1.15 & $0.66^{* *}$ & 0.79 & $0.49^{* *}$ & $0.77^{*}$ & $1.34^{*}$ & $1.50 \mathrm{E}-02$
\end{tabular}

Cell Growth and Cytoskeleton Organization

\begin{tabular}{lllllllllll}
\hline add1 & BF140063 & 0.99 & 0.96 & 1.16 & 0.96 & 0.85 & $2.57^{* *}$ & 0.86 & $3.93^{* *}$ & $1.94 \mathrm{E}-02$ \\
add1 & BF140063 & 0.82 & 0.80 & $0.62^{* *}$ & $0.56^{* *}$ & 1.25 & $2.41^{* *}$ & 1.24 & $0.44^{* *}$ & $8.01 \mathrm{E}-03$ \\
cap1 & NM_007598 & $4.88^{*}$ & 0.80 & 1.16 & 1.14 & 1.50 & $8.59^{* *}$ & 0.87 & $0.17^{* *}$ & $4.61 \mathrm{E}-02$ \\
cfl1 & NM_007687 & 1.29 & $0.51^{* *}$ & 1.30 & $1.89^{* *}$ & 1.03 & $2.28^{* *}$ & 1.15 & $2.14^{* *}$ & $4.26 \mathrm{E}-02$ \\
creg1 & BC027426 & 1.06 & 0.83 & $2.39^{* *}$ & $1.72^{* *}$ & 0.82 & $1.54^{*}$ & $0.69^{*}$ & 1.09 & $3.57 \mathrm{E}-02$ \\
creg1 & BC027426 & $2.08^{* *}$ & $2.12^{* *}$ & $1.60^{* *}$ & $2.16^{* *}$ & $0.69^{*}$ & 0.85 & 0.98 & 0.92 & $3.68 \mathrm{E}-02$ \\
egf & NM_010113 & 1.05 & 0.79 & 0.92 & $1.38^{*}$ & $1.62^{* *}$ & $0.47^{* *}$ & 0.91 & 0.84 & $1.28 \mathrm{E}-02$ \\
Isp1 & NM_019391 & 0.90 & $0.78^{*}$ & 0.97 & 1.10 & 1.02 & $3.42^{* *}$ & $0.67^{* *}$ & $1.90^{* *}$ & $3.22 \mathrm{E}-02$ \\
myh4 & BG794681 & 0.99 & 1.25 & 0.65 & 1.06 & 1.72 & $2.94^{*}$ & 0.94 & 1.55 & $8.16 \mathrm{E}-03$ \\
pdlim3 & NM_016798 & 1.00 & 1.09 & 1.07 & 0.78 & 0.85 & $2.73^{* *}$ & $1.49^{*}$ & $2.29^{* *}$ & $4.52 \mathrm{E}-02$
\end{tabular}


Table 1 Cell cycle and cell growth genes responsive to MYC-ER ${ }^{\text {TAM }}$ activation (Continued)

\begin{tabular}{|c|c|c|c|c|c|c|c|c|c|c|}
\hline plec1 & BM210485 & 1.31 & $0.49 *$ & 1.25 & $3.10^{* *}$ & 0.53 & 1.38 & 1.04 & $2.87^{* *}$ & $2.42 \mathrm{E}-02$ \\
\hline plec1 & BM232239 & 1.20 & 0.77 & 1.35 & $2.46^{* *}$ & $3.23^{* *}$ & $4.56^{* *}$ & $2.82^{* *}$ & $0.59^{*}$ & 2.09E-03 \\
\hline tuba3a & NM_009446 & 0.97 & 0.97 & 1.13 & 1.00 & 0.83 & $3.09^{* *}$ & 0.89 & $3.20^{* *}$ & $1.22 \mathrm{E}-02$ \\
\hline tubb6 & NM_026473 & 1.21 & 0.90 & $2.95^{* *}$ & $1.71^{*}$ & 0.97 & $2.99 * *$ & 1.28 & $3.49 * *$ & 2.41E-02 \\
\hline
\end{tabular}

Selected MYC-responsive genes relating to cell growth and cell proliferation. 'MYC-response p-value' is the p-value identified for the highest-order interaction of the MYC activation variable and represents the significance of this term within the selected model. Flags represent contrast p-values comparing $40 H T$-treated and vehicle-treated samples at specific time points $\left({ }^{\prime * \prime}, \mathrm{p} \leq 0.05{ }^{\prime * * * \prime} \mathrm{p} \leq 0.01\right)$. Cells are colour-coded based on a detected fold-change greater than 1.5 -fold (red, up-regulated; blue, down-regulated)

involved in degradation of $\mathrm{p} 27^{\mathrm{Kip} 1}$, increased from 8 hours following MYC activation in the pancreas. Interestingly, the $C d c 2 a$ gene, whose product $C d k 1$ is essential for mammalian cell division [49,50], was also found to be highly up-regulated in $\beta$-cells (Table 1 ). Cdk1 has been found to substitute for other CDKs to drive cell cycle progression [51], and is particularly associated with $\mathrm{Cdk} 4$ in $\mathrm{G}_{1} / \mathrm{S}$-phase progression [reviewed in 52]. This may indicate a significant role for Cdk1 in the promotion of cell cycle progression following MYC activation in $\beta$-cells. Alternatively, it has been shown that premature activation of Cdk1 can lead to mitotic catastrophe in $\mathrm{G}_{2} / \mathrm{M}$-phase and apoptosis (upstream of p53induced mitochondrial outer membrane permeabilization) in neurons [53]. Given that this CDK was also detected at later time points, this may indicate a possible role for Cdk1 in the MYC-induced apoptosis pathways. In addition to this, the CDK inhibitor $C d k n 2 c$ $\left(\mathrm{p} 18^{\text {Ink4c }}\right.$ ), which inhibits $\mathrm{G}_{1} / \mathrm{S}$-phase transition via interactions with Cdk4 [54] and Cdk6 [55], was down-regulated early in the pancreas. However, by 16 hours expression levels had risen dramatically, which may be indicative of cell cycle arrest prior to apoptosis. In addition, the CDK inhibitor Cdkn1a (p21 $\left.{ }^{\mathrm{Cip} 1}\right)$ - a downstream target of the tumour suppressor p53 - was upregulated at 8 hours (Table 1).

Growth arrest specific gene 6 (Gas6) was up-regulated in SBK (Table 1), and has been found to have different roles dependant on tissue location, including promotion of cell cycle progression in fibroblasts and Schwann cells [56,57], and has been shown to play a role in cellular survival by inducing signalling through the PI3K/Akt pathway leading to phosphorylation of the forkhead box protein Foxo1 in endothelial cells [58] and in oligodendrocytes of the central nervous system [59]. Interestingly, the growth arrest and DNA-damage-inducible 45 gamma gene, Gadd45g, a proposed MYC target whose product is involved in growth arrest at the $\mathrm{G}_{2} / \mathrm{M}$ DNA-damage checkpoint [60], showed increased expression at 4 hours in SBK, and remained 3fold up-regulated throughout the time course, whilst down-regulation at 8 hours was detected in $\beta$-cells. This suggests potential activation of pathways to limit unchecked proliferation in the keratinocytes (Table 1).
Genes relating to increased cellular mass, cytoskeleton organization and DNA replication were also detected for SBK (Additional file 1, Table S3), including the membrane skeletal proteins Adducin 1 (Add1) and Pdlim3, the actin-modulating protein Cofilin $1(C f l 1)$, members of the kinesin family of microtubule motor proteins, members of the myosin superfamily of actin binding motor proteins (e.g. Myh4, Myoc, Myo1f), and members of the tubulin family of microtubule proteins (Tuba3a, Tubb2c, Tubb6). Plectin 1 (Plec1), one of the main components of the cytoskeleton, showed an increase in expression of roughly 3- to 4-fold throughout the early stages of the time course (Table 1). This increased activity of microtubule formation and actin formation for both the pancreas and skin is indicative of increased cellular turnover in both tissues.

\section{Apoptotic response following MYC activation}

The ultimate phenotypic response to activation of MYC in pancreatic $\beta$-cells is apoptosis [27]. Immunohistological staining for Caspase 3, an early marker for initiation of apoptosis pathways, indicated an apoptotic response to MYC activation in the $\beta$-cells but not in the SBK (Figure 3A). In contrast, MYC-activated SBK that have begun a process of terminal differentiation, re-enter the cell cycle but are protected from conventional apoptosis $[33,38]$. These cells will ultimately be shed and removed from the surrounding micro-environment thus ridding the host of potentially harmful pre-cancerous cells [61]. Our array data confirm a large transcriptional response detected in genes relating to apoptosis and survival by gene ontology classification in both tissues (Figure 3B and Additional file 1 Table S4). A subset of important genes from this list is shown in Table 2.

Activation of MYC in pancreatic $\beta$-cells identified a significant change in expression for 92 genes relating to cell death and apoptosis. Of these, 42 genes showed an increase and 50 genes showed a decrease in expression (Additional file 1, Table S4). Early activation of key regulators of apoptosis featured prominently in these data. Activation of MYC in SBK resulted in significant changes in expression for 66 genes relating to apoptosis and cell survival, including 37 genes showing an increase 


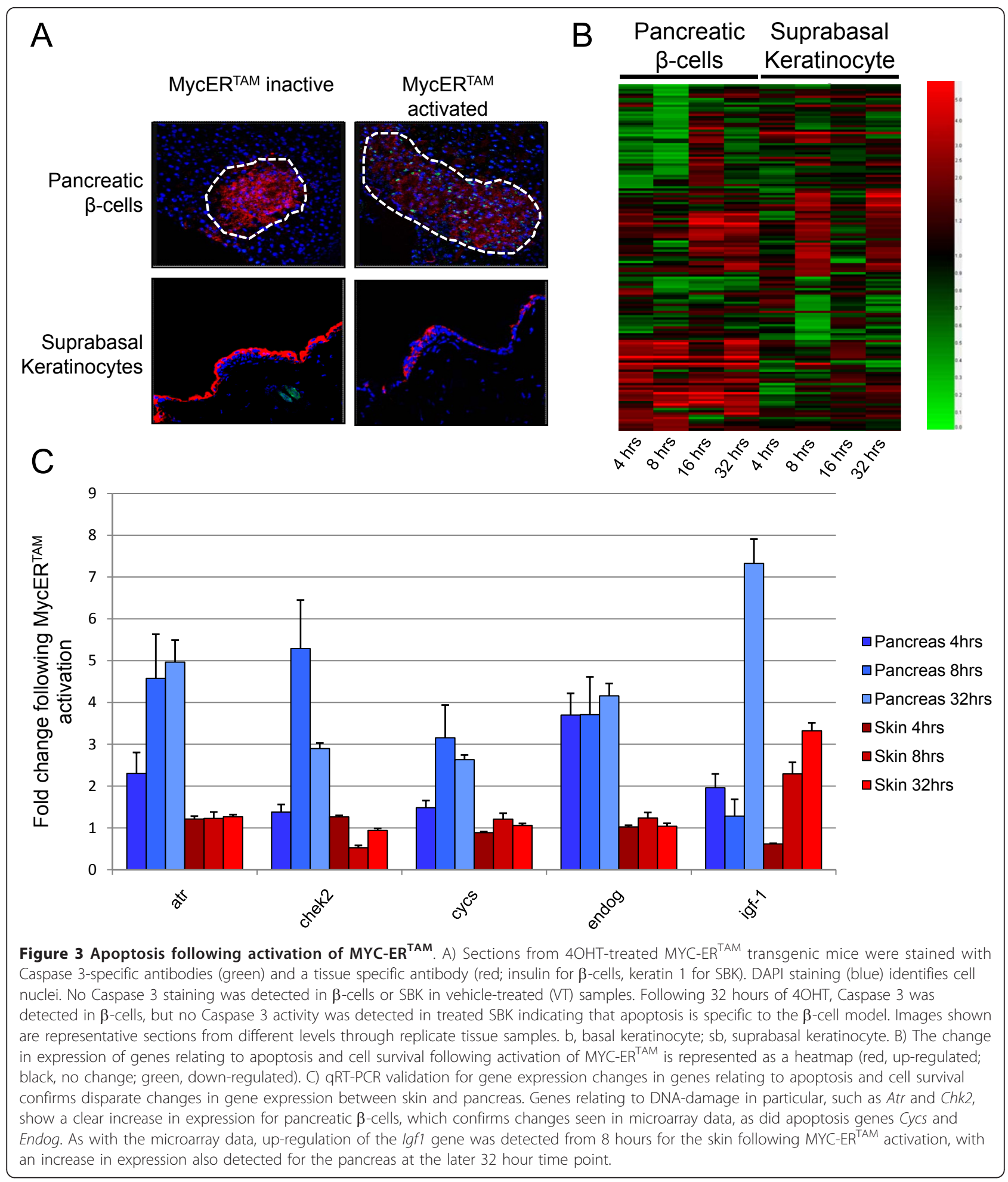

and 29 genes showing a decrease in expression (Additional file 1, Table S4).

The tumour suppressor $C d k n 2 a$, which encodes for the CDK inhibitor $\mathrm{p} 16^{\mathrm{Ink} 4 \mathrm{a}}$ and the alternative reading frame tumour suppressor $\mathrm{p} 19^{\mathrm{Arf}}$ (p14 ${ }^{\mathrm{Arf}}$ in humans), was up-regulated 2 -fold at 4 hours and remained at an elevated level throughout the time course for $\beta$-cells, but remained unchanged in SBK (Table 2 and Figure 3C). Previous studies have identified a possible role for the $\mathrm{p} 19^{\mathrm{Arf}} / \mathrm{p} 53 / \mathrm{Mdm} 2$ tumour suppressor pathway in 
Table 2 Apoptosis and cell survival genes responsive to MYC-ER ${ }^{\text {TAM }}$ activation

\begin{tabular}{lllllllll}
\hline & & \multicolumn{5}{c}{ Pancreatic $\beta$-Cells } & \multicolumn{5}{c}{ Suprabasal Keratinocytes } \\
\cline { 2 - 7 } Gene Symbol & RefSeq & 4 Hours 8 Hours & 16 Hours & 32 Hours & 4 Hours 8 Hours & 16 Hours & 32 Hours & Myc-response p-value \\
\hline
\end{tabular}

\begin{tabular}{|c|c|c|c|c|c|c|c|c|c|c|}
\hline Apoptosis & & & & & & & & & & \\
\hline$\overline{b a x}$ & BC018228 & 1.09 & $1.65^{* *}$ & $2.49^{* *}$ & $1.72^{* *}$ & $1.37^{*}$ & $1.70^{* *}$ & $1.87^{* *}$ & $1.99 * *$ & 4.61E-02 \\
\hline birc4 & BF134200 & $0.52^{*}$ & 0.64 & 1.76 & $1.77^{*}$ & 0.71 & 0.72 & 0.77 & 1.10 & $3.12 \mathrm{E}-02$ \\
\hline birc4 & BF134200 & $0.69^{*}$ & $0.58^{*}$ & 0.78 & 0.81 & $0.53^{* *}$ & $0.31^{* *}$ & 1.14 & 0.75 & $5.29 \mathrm{E}-03$ \\
\hline birc5 & BC004702 & $0.57^{*}$ & $1.99^{* *}$ & $16.53^{* *}$ & $1.90^{* *}$ & $0.61^{* *}$ & 1.13 & 1.06 & 1.25 & 8.88E-03 \\
\hline cdc2a & NM_007659 & 0.95 & $2.91^{* *}$ & $11.93^{* *}$ & $3.35^{* *}$ & $0.51^{*}$ & 1.17 & 0.89 & 1.12 & 4.33E-02 \\
\hline cdkn2a & NM_009877 & $2.17^{* *}$ & $1.79^{* *}$ & $1.57^{* *}$ & $2.61^{* *}$ & 1.21 & 1.07 & 1.07 & 0.87 & 8.43E-03 \\
\hline cflar & BE284491 & 1.03 & 0.97 & 1.00 & 0.94 & 1.04 & 1.00 & $1.28^{* *}$ & $2.34^{* *}$ & 4.59E-02 \\
\hline cflar & BE284491 & $0.82^{*}$ & 0.87 & $0.54^{* *}$ & $0.43^{* *}$ & 1.00 & 1.13 & 1.03 & 1.09 & $2.22 \mathrm{E}-02$ \\
\hline cflar & AK020765 & $0.78^{*}$ & $0.75^{*}$ & 1.18 & $0.51^{* *}$ & 1.05 & 1.16 & 1.01 & $0.73^{*}$ & 4.40E-02 \\
\hline cycs & NM_007808 & 0.96 & 0.87 & $2.54^{* *}$ & $2.38^{* *}$ & 0.99 & $1.62^{* *}$ & 0.96 & 0.91 & $2.84 \mathrm{E}-02$ \\
\hline cycs & NM_007808 & $1.17^{*}$ & $1.98^{* *}$ & $1.55^{* *}$ & $2.05^{* *}$ & $0.83^{*}$ & 1.00 & 1.17 & 1.05 & 1.64E-03 \\
\hline d2wsu81e & AV104666 & $2.85^{* *}$ & $2.94^{* *}$ & $1.50^{* *}$ & $1.85^{* *}$ & $0.74^{*}$ & 1.01 & 0.95 & 1.24 & 1.19E-05 \\
\hline endog & NM_007931 & $2.49^{* *}$ & $2.90^{* *}$ & $2.40^{* *}$ & $1.96^{* *}$ & $0.75^{*}$ & $1.46^{* *}$ & 1.20 & $1.74^{* *}$ & $2.48 \mathrm{E}-02$ \\
\hline fas & BG976607 & $6.55^{* *}$ & $6.15^{* *}$ & $3.85^{* *}$ & $11.34^{* *}$ & 0.82 & 1.22 & 1.61 & 1.35 & 3.79E-02 \\
\hline fas & BG976607 & $3.61^{* *}$ & $7.00^{* *}$ & 1.13 & $4.43^{* *}$ & 1.33 & 0.63 & 1.35 & $0.46^{* *}$ & $6.32 \mathrm{E}-03$ \\
\hline fas & BG976607 & $5.08^{* *}$ & $12.85^{* *}$ & $5.07^{* *}$ & $10.92^{* *}$ & 0.72 & $5.14^{* *}$ & 0.74 & $0.48^{*}$ & $1.12 \mathrm{E}-03$ \\
\hline fas & BG976607 & $2.43^{* *}$ & $1.78^{* *}$ & $2.28^{* *}$ & $2.50^{* *}$ & 0.83 & 1.33 & 1.09 & $0.39^{* *}$ & 2.21E-03 \\
\hline ing3 & BB298005 & 0.9 & 1.12 & 1.15 & $0.66^{* *}$ & 0.79 & $0.49^{* *}$ & $0.77^{*}$ & $1.34^{*}$ & $1.50 \mathrm{E}-02$ \\
\hline pmaip1 & NM_021451 & 1.15 & 1.13 & 1.02 & 0.85 & $1.33^{*}$ & $0.45^{* *}$ & $0.77^{*}$ & 0.87 & $6.77 \mathrm{E}-03$ \\
\hline tnfrsf12a & NM_013749 & $0.59^{* *}$ & 0.85 & $2.53^{* *}$ & $0.72^{* *}$ & 1.11 & $3.15^{* *}$ & $1.38^{* *}$ & 1.17 & 4.16E-02 \\
\hline tnfrsf12a & NM_013749 & 0.86 & 0.87 & $2.29^{* *}$ & 0.85 & 1.18 & $2.77^{* *}$ & $1.39^{* *}$ & 1.11 & 4.89E-03 \\
\hline tnfrsf4 & NM_011659 & 1.18 & $0.60^{*}$ & $1.46^{*}$ & $1.64^{* *}$ & 1.27 & $2.12^{* *}$ & $1.76^{* *}$ & 1.03 & $5.78 \mathrm{E}-03$ \\
\hline
\end{tabular}

\section{Cell Survival}

\begin{tabular}{lllllllllll}
\hline akt1 & NM_009652 & 1.01 & 0.97 & $1.71^{* *}$ & $2.31^{* *}$ & 0.82 & $3.23^{* *}$ & 0.95 & $2.29^{* *}$ & $4.43 \mathrm{E}-02$ \\
akt2 & NM_007434 & 1.00 & 1.05 & 0.98 & 1.13 & 1.27 & $2.21^{* *}$ & 1.02 & $2.26^{* *}$ & $7.85 \mathrm{E}-03$ \\
akt2 & BC026151 & 0.78 & 0.89 & $2.31^{* *}$ & $2.69^{* *}$ & 0.99 & $1.74^{* *}$ & 1.01 & $1.70^{* *}$ & $3.97 \mathrm{E}-02$ \\
igf1 & NM_010512 & $2.08^{*}$ & 0.63 & 0.74 & 1.20 & 1.17 & $2.33^{* *}$ & 1.47 & $2.00^{*}$ & $4.75 \mathrm{E}-02$ \\
igf1 & BG075165 & 0.97 & 1.11 & 1.25 & $2.11^{* *}$ & 1.03 & 1.09 & $2.34^{* *}$ & $3.54^{* *}$ & $4.66 \mathrm{E}-02$ \\
igf1 & AF440694 & 1.05 & 1.00 & 1.59 & $3.71^{* *}$ & $1.56^{*}$ & $2.24^{* *}$ & 1.24 & $3.08^{* *}$ & $4.10 \mathrm{E}-02$
\end{tabular}

\section{DNA-damage}

\begin{tabular}{lllllllllll}
\hline atm & NM_007499 & 0.84 & $0.43^{* *}$ & 1.12 & 1.08 & 0.90 & 0.92 & 1.46 & $0.60^{*}$ & $1.62 \mathrm{E}-04$ \\
atr & AF236887 & $2.25^{* *}$ & $3.79^{* *}$ & $2.71^{* *}$ & $2.76^{* *}$ & 1.17 & 1.17 & $1.44^{*}$ & $1.53^{* *}$ & $3.46 \mathrm{E}-02$ \\
chek1 & BB298208 & 1.10 & $3.70^{* *}$ & $2.35^{* *}$ & $1.92^{* *}$ & 0.91 & 1.03 & 1.31 & 1.23 & $4.05 \mathrm{E}-03$ \\
chek1 & C85740 & $1.94^{*}$ & $4.38^{* *}$ & $4.71^{* *}$ & $4.17^{* *}$ & 0.90 & $0.48^{*}$ & 1.28 & 1.03 & $1.62 \mathrm{E}-02$ \\
chek1 & NM_007691 & 1.37 & $1.79^{*}$ & $3.16^{* *}$ & $1.73^{* *}$ & 0.74 & 0.88 & 1.38 & 1.33 & $5.83 \mathrm{E}-03$ \\
chek2 & NM_016681 & 1.24 & $2.07^{* *}$ & $2.65^{* *}$ & $2.29^{* *}$ & 0.82 & $0.63^{*}$ & 1.13 & 1.34 & $1.98 \mathrm{E}-02$ \\
gadd45g & AK007410 & $0.59^{*}$ & $0.41^{* *}$ & $1.88^{* *}$ & $0.59^{* *}$ & $4.07^{* *}$ & $5.16^{* *}$ & $3.39^{* *}$ & $2.78^{* *}$ & $5.95 \mathrm{E}-03$ \\
h2afx & NM_010436 & 1.17 & $2.17^{* *}$ & $4.56^{* *}$ & $1.40^{* *}$ & $0.67^{* *}$ & $1.22^{*}$ & 0.97 & 1.01 & $3.43 \mathrm{E}-03$ \\
hus1 & NM_008316 & 0.85 & $1.97^{* *}$ & $2.04^{* *}$ & $1.62^{* *}$ & 0.97 & 0.96 & 1.24 & 1.23 & $1.46 \mathrm{E}-02$ \\
hus1 & AF076845 & 1.37 & 1.05 & $2.12^{* *}$ & 1.29 & 1.02 & 1.06 & 1.07 & 1.24 & $1.85 \mathrm{E}-02$ \\
rad1 & NM_011232 & $2.12^{* *}$ & $2.27^{* *}$ & $2.13^{*}$ & 1.58 & 0.67 & $3.18^{* *}$ & 0.79 & $1.94^{*}$ & $3.77 \mathrm{E}-03$ \\
rad51 & NM_011234 & 1.02 & $6.19^{* *}$ & $23.30^{* *}$ & $2.40^{* *}$ & 0.82 & 1.12 & $1.90^{* *}$ & 1.46 & $1.80 \mathrm{E}-02$
\end{tabular}

Selected MYC-responsive genes relating to apoptosis and cell survival. 'MYC-response $p$-value' is the p-value identified for the highest-order interaction of the MYC activation variable and represents the significance of this term within the selected model. Flags represent contrast $\mathrm{p}$-values comparing $4 \mathrm{OHT}$-treated and vehicle-treated samples at specific time points $\left({ }^{\prime * \prime}, \mathrm{p} \leq 0.05 ;{ }^{\prime * * \prime} \mathrm{p} \leq 0.01\right)$. Cells are colour-coded based on a detected fold-change greater than 1.5 -fold (red, upregulated; blue, down-regulated). 
MYC-mediated apoptosis $[62,63]$. Importantly, data from the Evan lab has elegantly shown that high levels of MYC-ER ${ }^{\text {TAM }}$ activation present in this transgenic model, led to expression of $\mathrm{p} 19^{\text {Arf }}$ concomitant with apoptosis [64]. In contrast, low levels of MYC-ER ${ }^{\mathrm{TAM}}$ activation did not induce apoptosis or $\mathrm{p} 19^{\text {Arf }}$ but rather $\beta$-cell proliferation. However, Finch et al. previously showed that loss of $19^{\text {Arf }}$ in $\beta$-cells of the MYC-ER ${ }^{\text {TAM }}$ transgenic model resulted in mainly increased proliferation, not suppression of apoptosis [65]. Thus the role of p19 ${ }^{\text {Arf }}$ in defending against aberrant oncogenic MYCinduced hyper-proliferation may be related to cell cycle arrest, and not directly to apoptosis pathways in $\beta$-cells.

The anti-apoptotic function of $\mathrm{Bclx}_{\mathrm{L}}$ seen in Rip7$\mathrm{Bcl}_{\mathrm{L}} / \mathrm{pIns}-\mathrm{MYC}-\mathrm{ER}^{\mathrm{TAM}}(\mathrm{RM})$ double transgenic mice indicates that MYC-induced apoptosis is related to the Bax/Bak-mediated intrinsic mitochondrial pathway $[27,66]$. Activation of this intrinsic apoptotic pathway was evident at the transcriptional level in $\beta$-cells by continued 2-fold increased expression of Bax and the somatic Cytochrome c gene (Cycs) from 16 hours onwards after MYC activation, and up-regulation of the mitochondrial respiratory gene for Endonuclease G, Endog, after only 4 hours of MYC activation. Both Bax $[67,68]$ and Cycs $[42,69]$ have been previously shown to be putative direct MYC targets due to the presence of non-canonical E-box MYC-Max binding sites, and association of MYC with the Bax promoter has been previously demonstrated through ChIP [68].

Gene expression profiling of pancreatic $\beta$-cells identified a strong and rapid induction of the DNA-damage response pathway (Table 2). A large increase in expression was detected after 8 hours of MYC activation for Rad51 and H2afx, previously identified MYC targets whose protein products are involved in homologous recombination and repair of DNA [70,71]. Also, significant up-regulation of Hus1 and Rad1 - whose products form the 9-1-1 DNA-damage sensing machinery with Rad9 - indicated that oncogenic stress through deregulation of MYC resulted in the induction of DNA double strand breaks. The gene for the DNA-damage mediator Atr was also found to be up-regulated by 2 -fold throughout the time course from 4 hours, and the associated checkpoint kinases $C h k 1$ and $C h k 2$ were up-regulated 2-fold from 8 hours (Table 2 and Figure 3C). The gene for the double-strand break-related DNA-damage mediator Atm showed 2-fold down-regulation at 8 hours, although it has been shown that Atm plays a significant role in MYC-induced apoptosis in lymphomagenesis in mice [72]. The genes Cdkn2a (p16/p19 ${ }^{\text {Arf }}$ ) $[2,62]$ and Atr [73] are previously categorized MYC target genes. The checkpoint kinase genes Chk1 and Chk2 have not been previously classified as MYC target genes, indicating that the observed changes in expression may occur downstream of Atr. Interestingly, as mentioned previously, expression of $C d k n 2 c\left(\mathrm{p} 18^{\mathrm{Ink} 4 \mathrm{c}}\right)$, which inhibits Cdk4/6, was significantly up-regulated (6-fold) in $\beta$ cells at 16 hrs. p18 ${ }^{\text {Ink4c }}$ interacts directly with Atm/Atr leading to an increase in $\mathrm{p} 53$ protein, and promotion of growth arrest and/or cell death, suggesting a link between $\mathrm{p} 18^{\text {Ink4c }}$ and the DNA-damage response pathways [74]. Comparatively few DNA-damage related genes showed significant changes in expression for SBK, although we cannot exclude the possibility that DNAdamage proteins may be regulated by MYC through non-transcriptional means (e.g. protein phosphorylation).

Of particular interest was the survival factor gene Igf1, whose product has been shown to inhibit MYC-induced apoptosis in vitro by blocking Cytochrome c release from the mitochondria through the Akt1 tumour suppressor pathway [75]. Igf1 was up-regulated throughout much of the time-course for SBK, and this was confirmed using qRT-PCR (Figure 3C). Consistent with this finding, $A k t 1$ was up-regulated 3-fold at 8 hours and 2fold at 32 hours. A similar pattern was observed for Akt2, a second member of the Akt protein kinase family. This strongly supports the view that activation of the Igf-Akt pathway may contribute to suppression of MYC-related apoptosis. Interestingly, Igf1, Akt1 and $A k t 2$ were up-regulated at later time points in $\beta$-cells. It is therefore possible that the Igf-Akt pathway is activated in both tissues, but that the $\beta$-cells may be able to bypass these signals.

The pro-apoptotic Bcl2 family member Pmaip1 (Noxa) and the gene encoding inhibitor of growth protein $\mathrm{p} 47^{\text {Ing3 }}$ (Ing3) both showed a decrease in expression of 2 -fold at 8 hours in SBK, but exhibited no change in $\beta$-cells (Table 2). Over-expression of $\mathrm{p} 47^{\text {Ing3 }}$ results in cell cycle arrest and apoptosis in cancer cell lines [76], and reduced expression and loss of heterozygosity of the $\mathrm{p} 47^{\text {Ing3 }}$ locus have been found to be associated with human head and neck squamous carcinomas [77]. Also seen were several members of the TNF superfamily of apoptosis-inducing receptors. Tnfrsf $12 a$, which has been found to be involved in inducing both apoptosis and angiogenesis $[78,79]$, showed an increase in expression in the skin of 3 -fold at 8 hours. Tnfrsf4, whose product has been implicated in promoting survival through induction of $\mathrm{Bcl} 2$ and $\mathrm{Bcl}_{\mathrm{XL}}$ expression in $\mathrm{CD} 4 \mathrm{~T}$ cells [80], similarly showed an increase in expression of 2 fold at 8 hours.

\section{A pro-angiogenic response in suprabasal epidermis}

The placental growth factor gene, $P g f$, showed a marked increase from 8 hours throughout the time course for the skin (Table 3). In contrast, a 2-fold down-regulation was detected for the pancreas throughout much of the 


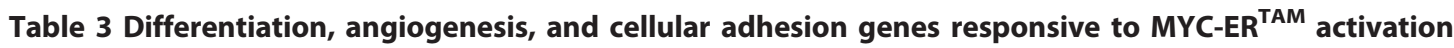

\begin{tabular}{|c|c|c|c|c|c|c|c|c|c|c|}
\hline \multirow[b]{2}{*}{ Gene Symbol } & \multirow[b]{2}{*}{ RefSeq } & \multicolumn{4}{|c|}{ Pancreatic $\beta$-Cells } & \multicolumn{4}{|c|}{ Suprabasal Keratinocytes } & \multirow[b]{2}{*}{ Myc-response $p$-value } \\
\hline & & 4 Hours & 8 Hours & 16 Hours & 32 Hours & 4 Hours & 8 Hours & 16 Hours & 32 Hours & \\
\hline \multicolumn{11}{|l|}{ Differentiation } \\
\hline adamts1 & D67076 & 0.56 & 0.72 & $2.12^{*}$ & 1.10 & 1.42 & 1.33 & $3.29^{* *}$ & $3.42^{* *}$ & 2.89E-02 \\
\hline creg1 & BC027426 & $2.08^{* *}$ & $2.12^{* *}$ & $1.60^{* *}$ & $2.16^{* *}$ & $0.69 *$ & 0.85 & 0.98 & 0.92 & $3.68 \mathrm{E}-02$ \\
\hline csta & C89521 & 1.12 & 1.13 & 1.04 & 0.88 & $0.49^{* *}$ & 1.04 & $0.34^{* *}$ & $0.52^{* *}$ & $1.28 \mathrm{E}-02$ \\
\hline eg666231 & C81193 & $1.26^{*}$ & $1.85^{* *}$ & $2.40^{* *}$ & $1.98^{* *}$ & $0.82^{*}$ & $2.76^{* *}$ & 1.19 & $2.29^{* *}$ & $1.94 \mathrm{E}-02$ \\
\hline gck & L38990 & $0.59^{*}$ & $0.14^{* *}$ & $2.46^{* *}$ & 0.81 & 1.14 & 1.41 & 1.27 & 1.29 & $2.31 \mathrm{E}-03$ \\
\hline ins1 & NM_008386 & $0.18^{*}$ & 0.42 & $9.94^{* *}$ & $10.18^{* *}$ & 1.55 & 1.14 & 1.46 & 1.26 & $1.80 \mathrm{E}-03$ \\
\hline ins2 & NM_008387 & $0.17^{*}$ & 0.36 & $8.70^{* *}$ & $12.66^{* *}$ & 0.57 & 1.36 & 1.00 & 0.77 & $1.03 \mathrm{E}-03$ \\
\hline ivl & AV009441 & 0.99 & 1.24 & 1.06 & 1.03 & $0.35^{* *}$ & $0.59^{* *}$ & $0.22^{* *}$ & 0.82 & 4.32E-02 \\
\hline krt1 & NM_008473 & $1.49^{*}$ & 0.99 & 1.17 & 1.02 & $0.48^{* *}$ & $4.02^{* *}$ & $0.70^{*}$ & 0.86 & 4.05E-02 \\
\hline krt14 & BC011074 & 1.26 & $1.43^{*}$ & 1.16 & $0.73^{*}$ & 0.89 & $2.02^{* *}$ & 0.96 & 0.98 & $1.93 \mathrm{E}-02$ \\
\hline krt14 & BC011074 & 1.12 & 1.00 & 1.16 & 0.98 & 0.91 & $2.17^{* *}$ & 0.89 & 1.04 & 2.87E-02 \\
\hline $\mathrm{mnx} 1$ & NM_019944 & $0.57^{*}$ & $0.40^{* *}$ & 0.88 & 1.40 & 0.88 & 1.03 & 1.06 & 0.96 & $1.07 \mathrm{E}-02$ \\
\hline$n k \times 2-2$ & NM_010919 & 0.65 & $0.66^{*}$ & 1.55 & $0.43^{* *}$ & 0.91 & 0.76 & 0.97 & $0.65^{*}$ & $2.22 \mathrm{E}-02$ \\
\hline$n k x 6-1$ & AF357883 & $0.53^{*}$ & $0.32^{* *}$ & $2.29^{* *}$ & 1.13 & 0.91 & 0.94 & 1.09 & 0.98 & 4.29E-02 \\
\hline odc1 & S64539 & $1.72^{* *}$ & $2.29^{* *}$ & $1.83^{* *}$ & $1.82^{* *}$ & 1.11 & $1.62^{* *}$ & 0.99 & $1.81^{* *}$ & $2.43 \mathrm{E}-02$ \\
\hline pent & NM_008787 & $2.70^{* *}$ & $3.79 * *$ & $5.22^{* *}$ & $4.18^{* *}$ & 1.14 & $1.89^{* *}$ & 1.1 & $1.82^{* *}$ & $1.37 \mathrm{E}-02$ \\
\hline pcsk2 & BB357975 & $2.24^{* *}$ & $0.56^{*}$ & $0.69^{*}$ & 1.08 & 1.24 & 1.12 & 1.04 & 0.83 & $1.33 \mathrm{E}-02$ \\
\hline pcsk2 & Al839700 & 0.98 & $0.48^{* *}$ & $0.71^{* *}$ & 0.93 & 1.03 & 1.08 & 0.89 & 0.89 & 3.31E-02 \\
\hline pcsk2 & NM_008792 & $0.42^{* *}$ & $0.39^{* *}$ & $1.74^{* *}$ & $2.59^{* *}$ & 0.94 & 1.01 & 1.10 & 0.96 & 4.15E-02 \\
\hline $\mathrm{pdx} 1$ & AK020261 & $0.74^{*}$ & $0.20^{* *}$ & $0.71^{*}$ & $0.47^{* *}$ & $1.96^{* *}$ & 1.11 & 1.30 & 0.95 & $3.47 \mathrm{E}-02$ \\
\hline $\mathrm{pdx} 1$ & AK020261 & $0.60^{* *}$ & $0.37^{* *}$ & $0.70^{*}$ & $0.62^{* *}$ & 1.11 & 1.08 & 1.20 & 0.92 & 4.14E-02 \\
\hline plec1 & BM210485 & 1.31 & $0.49^{*}$ & 1.25 & $3.10^{* *}$ & 0.53 & 1.38 & 1.04 & $2.87^{* *}$ & $2.42 \mathrm{E}-02$ \\
\hline plec1 & BM232239 & 1.20 & 0.77 & 1.35 & $2.46^{* *}$ & $3.23^{* *}$ & $4.56^{* *}$ & $2.82^{* *}$ & $0.59^{*}$ & 2.09E-03 \\
\hline slc2a2 & NM_031197 & $0.84^{*}$ & $0.43^{* *}$ & 0.94 & $0.76^{* *}$ & $0.74^{* *}$ & 1.00 & $1.19^{*}$ & 0.91 & 2.91E-02 \\
\hline sprr1b & NM_009265 & 1.14 & 1.13 & 1.10 & 0.76 & $0.24^{* *}$ & $0.33^{* *}$ & 0.67 & $0.27^{* *}$ & $1.27 \mathrm{E}-02$ \\
\hline $\operatorname{tgm} 2$ & BC016492 & 1.21 & 0.74 & $8.27^{* *}$ & $2.63^{* *}$ & 0.83 & $1.89^{*}$ & $2.02^{* *}$ & $4.55^{* *}$ & $1.54 \mathrm{E}-03$ \\
\hline $\operatorname{tgm} 2$ & AW321975 & 1.15 & $1.47^{*}$ & $3.90^{* *}$ & $3.73^{* *}$ & 1.09 & 0.79 & $1.89^{* *}$ & 1.03 & $1.54 \mathrm{E}-02$ \\
\hline $\operatorname{tgm} 2$ & BB550124 & $1.37^{*}$ & $1.36^{*}$ & $3.44^{* *}$ & $2.75^{* *}$ & 1.26 & $0.70^{*}$ & $1.91^{* *}$ & 1.04 & $1.58 \mathrm{E}-02$ \\
\hline $\operatorname{tgm} 2$ & BB041811 & $1.31^{*}$ & $1.52^{* *}$ & $3.05^{* *}$ & $3.22^{* *}$ & 1.01 & $0.65^{* *}$ & $2.30^{* *}$ & 1.22 & $2.44 \mathrm{E}-02$ \\
\hline \multicolumn{11}{|l|}{ Cell Adhesion } \\
\hline itga7 & NM_008398 & 0.85 & 0.86 & $1.40^{*}$ & $2.86^{* *}$ & $0.50^{*}$ & $1.67^{*}$ & 0.76 & $2.48^{* *}$ & $2.14 \mathrm{E}-02$ \\
\hline itga9 & NM_133721 & 1.16 & $1.81^{*}$ & 1.14 & 1.15 & 0.82 & 1.45 & 1.12 & $2.11^{* *}$ & $3.56 \mathrm{E}-02$ \\
\hline itgb2 & NM_008404 & 1.27 & 1.00 & $2.18^{* *}$ & $3.99 * *$ & 1.27 & $2.81^{* *}$ & 0.65 & $4.16^{* *}$ & 8.45E-03 \\
\hline itgb3 & AV352983 & 0.83 & 0.88 & $1.30^{*}$ & $0.76^{*}$ & 1.12 & $1.54^{* *}$ & $1.94^{* *}$ & $2.33^{* *}$ & 4.47E-03 \\
\hline itgb6 & NM_021359 & 0.96 & 0.97 & 0.95 & 1.04 & 1.11 & $2.22 * *$ & $1.33^{* *}$ & $1.55^{* *}$ & $3.45 \mathrm{E}-02$ \\
\hline kl & BQ175355 & 0.81 & $0.35^{* *}$ & 0.92 & 0.86 & 1.04 & 1.09 & 0.87 & 0.89 & $2.13 \mathrm{E}-02$ \\
\hline \multicolumn{11}{|c|}{ Immune Response } \\
\hline$\overline{\text { h2-aa }}$ & AV086906 & $3.97^{*}$ & 1.76 & 0.65 & $4.15^{*}$ & $0.27^{*}$ & $15.37^{* *}$ & 0.48 & 0.92 & $6.05 \mathrm{E}-03$ \\
\hline h2-d1 & M34962 & 2.81 & $2.55^{*}$ & 1.40 & $5.07^{* *}$ & $0.28^{*}$ & $39.62^{* *}$ & 0.53 & 1.31 & 2.31E-03 \\
\hline h2-I & M86502 & 2.32 & 1.79 & 1.83 & $6.04^{*}$ & 0.24 & $65.12^{* *}$ & 0.8 & 1.04 & $5.14 \mathrm{E}-03$ \\
\hline h2-I & M69068 & 2.71 & 1.98 & 1.72 & $6.72^{* *}$ & 0.32 & $48.04^{* *}$ & 0.64 & 0.91 & 4.38E-02 \\
\hline il1r1 & NM_008362 & $0.53^{* *}$ & $0.41^{* *}$ & $1.56^{*}$ & $0.62^{*}$ & $0.57^{* *}$ & 1.29 & 1.02 & 1.33 & $5.95 \mathrm{E}-03$ \\
\hline il6ra & X53802 & $0.35^{* *}$ & $0.45^{*}$ & 0.87 & $0.42^{* *}$ & 1.40 & 0.77 & 1.06 & 0.70 & 4.70E-03 \\
\hline \multicolumn{11}{|l|}{ Angiogenesis } \\
\hline cst7 & NM_009977 & 0.92 & 0.90 & $1.22^{*}$ & 1.10 & 1.04 & $1.99 * *$ & 0.95 & $1.45^{* *}$ & $1.79 \mathrm{E}-02$ \\
\hline pgf & NM_008827 & $0.50^{* *}$ & $0.39 * *$ & 1.03 & $0.43^{* *}$ & 1.03 & $2.29^{* *}$ & $2.24^{* *}$ & $6.64^{* *}$ & $2.52 \mathrm{E}-02$ \\
\hline
\end{tabular}


Table 3 Differentiation, angiogenesis, and cellular adhesion genes responsive to MYC-ER ${ }^{\text {TAM }}$ activation (Continued)

\begin{tabular}{lllllllllll}
\hline vegfa & NM_009505 & $0.83^{*}$ & $0.52^{* *}$ & 0.99 & 0.87 & 1.19 & $2.00^{* *}$ & 1.16 & $0.73^{*}$ & $4.27 \mathrm{E}-02$ \\
vegfa & U50279 & 1.16 & $0.32^{* *}$ & 1.12 & 0.65 & 0.86 & $1.79^{*}$ & 1.16 & 1.02 & $4.07 \mathrm{E}-02$ \\
vegfb & $\mathrm{U} 48800$ & 1.34 & 1.21 & $2.29^{* *}$ & $2.08^{* *}$ & $0.57^{*}$ & $1.72^{*}$ & 0.88 & 1.33 & $2.16 \mathrm{E}-02$ \\
vegfc & BB089170 & 1.18 & $0.69^{* *}$ & $0.60^{* *}$ & $1.72^{* *}$ & $0.76^{*}$ & $0.40^{* *}$ & 0.81 & $0.77^{*}$ & $2.21 \mathrm{E}-02$ \\
vegfc & AW228853 & 1.25 & 0.70 & 0.80 & $3.87^{* *}$ & $0.38^{* *}$ & 0.51 & 0.79 & 1.82 & $3.87 \mathrm{E}-02$
\end{tabular}

Extracellular Matrix

\begin{tabular}{|c|c|c|c|c|c|c|c|c|c|c|}
\hline $\mathrm{klk1}$ & BC010754 & 0.74 & 1.44 & 1.12 & 1.74 & 1.95 & $11.58^{* *}$ & $20.38^{* *}$ & $244.79 * *$ & $1.13 \mathrm{E}-04$ \\
\hline klk1 & BC010754 & 1.31 & 1.36 & 1.01 & 1.93 & $2.72^{*}$ & $16.74^{* *}$ & $13.93^{* *}$ & $255.71^{* *}$ & 4.94E-05 \\
\hline klk21 & AB039276 & $0.63^{* *}$ & 0.87 & 1.24 & 1.12 & 1.11 & $3.36^{* *}$ & $4.16^{* *}$ & $17.78^{* *}$ & 4.06E-07 \\
\hline klk24 & NM_010643 & $0.60^{*}$ & 0.81 & 1.24 & 1.15 & $1.64^{*}$ & $4.99^{* *}$ & $12.91^{* *}$ & $18.13^{* *}$ & $3.33 \mathrm{E}-06$ \\
\hline klk27 & NM_020268 & 0.78 & 1.03 & 1.15 & 1.1 & 1.55 & $12.63^{* *}$ & $45.42^{* *}$ & $128.74^{* *}$ & 5.94E-08 \\
\hline klk9 & M17962 & 0.86 & 1.16 & 1.18 & 0.99 & 1.67 & $5.97^{* *}$ & $9.03^{* *}$ & $45.34^{* *}$ & $1.11 \mathrm{E}-04$ \\
\hline pgf & NM_008827 & $0.50^{* *}$ & $0.39^{* *}$ & 1.03 & $0.43^{* *}$ & 1.03 & $2.29^{* *}$ & $2.24^{* *}$ & $6.64^{* *}$ & $3.14 \mathrm{E}-02$ \\
\hline thbs2 & NM_011581 & 0.98 & 0.95 & 1.2 & 1.00 & 1.14 & $1.44^{* *}$ & $1.90^{* *}$ & $3.92^{* *}$ & $2.56 \mathrm{E}-07$ \\
\hline thbs 2 & BB233297 & 0.87 & 1.17 & 0.83 & 1.21 & $2.05^{* *}$ & $2.86^{* *}$ & $4.37^{* *}$ & $3.14^{* *}$ & 1.17E-03 \\
\hline thbs2 & NM_011581 & 0.99 & 0.94 & 0.99 & 1.05 & $2.23^{* *}$ & $2.60^{* *}$ & $5.86^{* *}$ & $3.40^{* *}$ & 4.14E-04 \\
\hline
\end{tabular}

Selected MYC-responsive genes relating to differentiation, angiogenesis and cellular adhesion. 'MYC-response p-value' is the p-value identified for the highestorder interaction of the MYC activation variable and represents the significance of this term within the selected model. Flags represent contrast $\mathrm{p}$-values comparing $4 \mathrm{OHT}$-treated and vehicle-treated samples at specific time points $\left({ }^{\prime * \prime}, \mathrm{p} \leq 0.05 ;{ }^{* * \prime} \mathrm{p} \leq 0.01\right)$. Cells are colour-coded based on a detected fold-change greater than 1.5-fold (red, up-regulated; blue, down-regulated)

time-course. Pgf is a member of the vascular endothelial growth factor (VEGF) family, and has been shown to result in increased numbers, branching and size of dermal blood vessels following over-expression in basal keratinocytes of adult mice [81]. This may indicate a role in the development of neovasculature seen following MYC activation in the SBK [28]. Vegfa, a further member of the VEGF family important in angiogenesis, was downregulated in the pancreas but showed up-regulation in the skin at 8 hours. In contrast, Vegfc, important in the growth of lymphatic vessels, showed down-regulation in the skin at early time points, but was up-regulated almost 4-fold in the pancreas at the later 32 hour timepoint. Vegfb showed a 2-fold increase from 16 hours in pancreas compared to no change in the skin. These results indicate a transcriptional response upon MYC activation for genes relating to neovascular growth.

\section{Activation of MYC leads to loss of differentiation}

Activation of MYC is often associated with loss of differentiation of cells and has been found to block terminal differentiation in a variety of cell types $[11,82,83]$. Activation of MYC in the pancreatic $\beta$-cells resulted in down-regulation of Ins 1 and Ins 2 by $>5$-fold at 4 hours, indicating acute loss of Insulin production within a short time period following MYC-deregulation. However, the expression levels of both subsequently increased dramatically showing almost 10 -fold up-regulation from 16 hours (Table 3). Since the islet area used for RNA extraction was roughly identical for each sample, this indicates acute increase in the levels of Insulin production within the $\beta$-cells in response to continuous MYC activation, and not in response to an increase in $\beta$-cell mass. Although perhaps a paradox at first glance, this response may be the result of a positive feedback loop due to increased Insulin release into the bloodstream immediately following MYC activation as we have previously shown [23]. Observation of transcript levels of both mRNAs at a later time point ( 72 hours; data not shown) indicated that this period of high Insulin production is limited, as gene expression subsequently returned to lower levels indicative of loss of $\beta$ cell differentiation. This indicates a short window within the first two days where a balance is struck between an increased rate of Insulin production and the simultaneous loss of cells due to MYC-driven apoptosis.

Members of the homeodomain transcription factor family, Pdx1, Pax4, Hb9, Nkx2.2 and Nkx6.1, are essential in pancreatic development [84]. Probe-sets for the pancreatic and duodenal homeobox gene $P d x 1$ (or Ipf1), whose product activates transcription of the Insulin gene as well as a number of genes involved in glucosesensing [85], showed a significant loss ( $>3$-fold) in expression at 8 hours following MYC activation (as well as potentially significant loss in expression $<2$-fold at all other time points), which correlated with the early reduction seen in Insulin production (Table 3). The transcription factor gene $N k \times 6.1$, whose product is essential for $\beta$-cell differentiation [86], also showed significant down-regulation in the early stages of MYC activation, although expression of this gene was shown to increase during later stages. Further Pdx1-regulated 
genes Slc2a2 (Glut2; previously classed as a putative MYC target gene) and Gck (Glucokinase), both part of the glucose-sensing machinery and involved in membrane transport and phosphorylation of glucose respectively, also followed similar expression profiles (Table 3). $\mathrm{Gu}$ et al. identified a group of 217 mature islet-specific genes [87], 63 of which showed a significant response following MYC activation in our analysis (Additional file 1, Table S6). The majority of these showed down-regulation at early time points. These data indicate a loss in $\beta$-cell differentiation and carbohydrate metabolism function following activation of MYC.

Activation of MYC in the SBK resulted in significant changes in expression of many genes relating to differentiation (Additional file 1, Table S5). In particular, it was clear that the primary result of MYC activation on these genes was down-regulation, with 199 differentiation-related genes showing a loss of expression compared to only 112 showing up-regulation. In addition to these general differentiation markers, activation of MYC led to down-regulation of several key keratinocyte differentiation genes (Table 3). Most notable was a significant 3 -fold decrease in expression for the Involucrin gene, $I v l$, after only 4 hours that was maintained throughout much of the time course. Involucrin is a key factor in the progression of differentiation of keratinocytes which works together with its substrate transglutaminase to cross-link with membrane proteins and provide support to the cell [88].

Cornifin (Sprr1b), a precursor to the epidermal cornified envelope, is a further keratinocyte differentiation markers that has been shown to affect the number of distinct layers of differentiated keratinocytes $[89,90]$. As with $I v l$, Sprr1b showed consistently marked down-regulation throughout the time course (Table 3). Similarly, Cystatin A (Csta), a cysteine protease inhibitor that is found expressed in keratinocytes as the precursor of the cornified cell envelope [91,92], showed $>2$-fold downregulation throughout much of the time course. Up-regulation of $\alpha$ and $\beta$ integrin genes such as Itga7, Itga 9, Itgb2, Itgb3 and Itgb6, particularly at later time points, suggests altered adhesion of SBK with surrounding cells and the extracellular matrix following MYC activation (Table 3). Also, expression changes were detected for several Keratin genes, including up-regulation of the suprabasal-specific Krt1 and the basal-specific Krt14 at 8 hours (Table 3 ), which encode fibrous structural proteins in keratinocytes.

Previous findings from the Watt group in which MYC is targeted to basal keratinocytes has, in contrast, shown that activation of MYC promotes an increase in the number of proliferating keratinocytes concomitant with promotion of terminal differentiation of epidermal stem cells [89]. In the microarray experiment of Frye et al.
[90], gene expression signatures were compared between whole skin sections from 4OHT-treated K14-MYC$\mathrm{ER}^{\mathrm{TAM}}$ mice and 4OHT-treated WT mice to identify cellular networks involved in the promotion of terminal differentiation of epidermal stem cells at the expense of hair lineages [90]. Activation of MYC for 4 days was sufficient to cause hyperproliferation of the interfollicular epidermis, with increased expression of genes relating to both proliferation (e.g. Ki67, Krt17, Krt6, Cdc2, $\mathrm{Cdc20}$ ) and interfollicular epidermis differentiation (Filaggrin and Cornifin/Sprp1). In contrast, expression of genes relating to early G1/S-phase cell cycle progression are more prominent when MYC is activated in SBK, whilst keratinocyte-specific differentiation genes such as Sprp1 generally show down-regulation. This suggests that activation of MYC suppresses differentiation in keratinocytes already undergoing terminal differentiation (i.e. SBK) to allow proliferation.

In a more recent study, low, intermediate, or high levels of MYC activity were induced in basal keratinocytes, and showed that MYC drives proliferation at all levels, but at high levels MYC promotes keratinocyte differentiation [93]. Promotion of differentiation may therefore act as a fail-safe mechanism against neoplastic conversion of epidermal stem cells.

\section{The transcriptome fingerprint of MYC activation is varied} in distinct tissues: pancreatic islets and skin

Clustering of genes whose expression changed significantly due to the joint effects of MYC activation and the tissue type identified genes whose expression profiles were correlated across the time courses for the two tissues, indicating possible co-regulation and functional similarity. Genes relating to DNA replication, DNAdamage checkpoint and cell cycle showed tight co-regulation, and showed significantly increased expression in the pancreatic $\beta$-cells. The expression profiles of minichromosome maintenance (MCM) deficient genes Mcm2, Mcm5, Mcm6 and Mcm7, whose products make up part of the MCM complex involved in DNA unwinding [94], the $C d t 1$ gene, whose product is involved in association of the MCM complex with chromatin, and various helicase related genes were found to be closely related, indicated co-expression of genes relating primarily to DNA replication. Close correlation with these genes was also seen in the pancreas for DNA-damage checkpoint related genes Atr and Chk1. These genes showed consistently high levels of expression in the $\beta$ cells, indicating a key role for DNA-damage response and repair in MYC-induced apoptosis. Conversely, no significant change was detected for these genes in the SBK.

In SBK, close correlation was detected for genes involved in proteolysis, particularly members of the 
Kallikrein family of serine proteases. Expression of Kallikrein genes (Klk1, Klk9, Klk21, Klk24 and Klk27) was found to increase significantly within 8 hours following activation of MYC, and continued to increase dramatically throughout the time course (Table 3 and Figure 1C). Klk1 and Klk9 have previously been found to be expressed throughout the epidermis of normal human skin [95], and play a role in degradation of the extracellular matrix (ECM) and loss of squamous cells during differentiation. Deregulated expression of Kallikreins has also been implicated in many cancer types [96-101]. The mouse Kallikreins Klk21, Klk24 and Klk27 have also been shown to be functionally active within the testes, both in degradation of the extra-cellular matrix and initiation of survival through degradation of Igf1bp3 [102-104]. Kallikrein proteins have been associated with angiogenesis. Growth of new vasculature is facilitated by regulating the tissue micro-environment, particularly through degradation of the extra-cellular matrix often via activation of matrix metalloproteinases (MMPs). This indicates a functional relationship between Kallikreins and the vascularisation-related gene, placental growth factor $\operatorname{Pgf}$ (a member of the vascular endothelial growth factor family of angiogenesis-related genes) and the Thrombospondin 2 gene Thbs 2 (an anti-angiogenic factor which has been linked to extra-cellular matrix remodelling through modulation of matrix metalloproteinases [105]) which showed close correlation with these genes. Given the prominent angiogenic phenotype that develops in these pre-cancerous skin lesions following MYC activation [33], it is reasonable to speculate here that Kallikreins and Pgf may be involved.

\section{Conclusions}

Deregulation or over-expression of the MYC onco-protein is a frequent feature of human cancers, which attests to the pleiotropic role that ectopic MYC plays in cellular function. However, oncogenic MYC can also trigger activation of intrinsic tumour suppressor programs such as $\mathrm{p} 19^{\mathrm{Arf}} / \mathrm{p} 53$, which serve to limit propagation of such harmful cells by inducing growth arrest or apoptosis. While much is known about the mechanisms of MYC functions, the pathways responsible for deciding the ultimate fate of the cell between 'life' (uncontrolled proliferation) and 'death' (i.e. apoptosis) in vivo are not yet clear. The decision for a cell to become apoptotic depends on the complex interactions of many pro- and anti-apoptotic factors. Different tissues may exhibit varying levels of these factors ultimately determining the fate of a cell. However, tissue-specific environmental characteristics can also affect the interaction between these factors, having a decisive effect on cell fate. The MYC$\mathrm{ER}^{\mathrm{TAM}}$ transgenic mouse model allows controlled overexpression of MYC in distinct adult tissues, SBK (epidermis) and pancreatic $\beta$-cells, enabling tracking of early changes downstream of aberrant MYC activity. In this study, high-throughput transcriptional profiling was used to identify transcriptional events that may provide clues to explain the disparity in the phenotypic response to MYC activation in SBK (proliferation and survival) and pancreatic $\beta$-cells (proliferation and apoptosis).

Whilst expression of genes relating to multiple cellular functions (eg. metabolic, transcriptional, transportational, ribosome biogenesis) is common to both tissues, expression of genes involved in DNA-damage and replication is enriched to $\beta$-cells. Consistent with early increased expression of Ki67 in $\beta$-cells [27], key $G_{1} / S$ phase genes (e.g. those encoding Cyclin D2, Cyclin E and Cdk4) showed early changes in expression, whilst $\mathrm{G}_{2} / \mathrm{M}$-phase genes (e.g. those encoding Cyclin A and Cyclin B) showed changes at later time points. Downregulation of the cyclin-dependent kinase inhibitor (CDKI) Cdkn1b (p27 ${ }^{\mathrm{Kip} 1}$ ) gene in $\beta$-cells was evident as previously shown in other cell types [48]. The CDKI $C d k n 2 c\left(\mathrm{p} 18^{\text {Ink4c }}\right)$, which inhibits Cdk4 and Cdk6, was also down-regulated, consistent with $\mathrm{G}_{1} / \mathrm{S}$ phase transition. The short time period over which these changes were seen supports the idea that MYC-induced cell cycle progression occurs through direct activation of key cell cycle genes such as Ccnd1, Ccnd2 and Ccne2.

In SBK, although there were changes in cell cycle related genes, the response was much less prominent in comparison with $\beta$-cells. Gene expression changes included up-regulation of Krt6a, Pcna, Ccnd3, Cdk4, and the key G1/S phase cyclin gene Ccnd2, accompanied by significant down-regulation of the CDKI gene $C d k n 1 b\left(\mathrm{p} 27^{\mathrm{Kip} 1}\right)$ throughout the time course. However, further cell cycle related genes (e.g. Ccna1, Ccne2 and $C d k 2$ ) did not appear to be measurably affected by MYC activation in SBKs. It is possible that SBK may at some point struggle to progress through the $G_{2} / M$ phase, which may be indicated by down-regulation of Ccnb1 and $C d c 2 a$, whose products are essential in later cell cycle stages. This contrasts with pancreatic $\beta$-cells, in which we found both $C c n b 1$ and $C d c 2 a$ significantly upregulated. The less pronounced cell cycle response in skin may be due to the relatively low proportion of keratinocytes that are responsive to Myc-induced proliferation at these early time-points. It has previously been shown that there is only a narrow window when very early suprabasal cells that have migrated out of the basal layer, are capable of responding to Myc-induced cell cycle entry $[28,105]$. The more differentiated keratinocytes of the granular layer are refractory to the proliferative influence of MYC.

Gene expression profiling of the pancreatic $\beta$-cells identified the DNA-damage checkpoint pathway as a likely route by which MYC mediates apoptosis in this 
system, leading to downstream activation of p53 and Bax-mediated release of Cytochrome c from the mitochondria. In addition, close correlation was seen in the pancreas for DNA-damage checkpoint related genes Atr and Chk1, and members of the MCM complex, Mcm2, $M c m 5$ and $M c m 7$. The change in expression for these genes following MYC activation was consistently high in the $\beta$-cells, suggesting a key role for DNA-damage response and repair in MYC-induced apoptosis. Conversely, no significant change was detected for these genes in the SBK. Recent evidence strongly suggests that deregulated MYC induces rapid accumulation of DNAdamage, which is the primary cause of activation of the Atm/Atr-dependant checkpoint [106,107]. The study of Dominguez-Sola et al. (2007), in particular, suggests that the pleiotropic role of MYC is due not only to transcriptional regulation of downstream genes, but also due to direct interactions with the DNA. This study also showed that over-expression of MYC results in DNAdamage and checkpoint activation. Consequently, the activation of DNA-damage response (DDR) pathways results in ultimate destruction of the offending cell.

Whilst direct control of these genes by MYC is not discernible from these data, it is clear that MYC deregulation induces a transcriptional response representative of cells undergoing DNA repair, which is a likely explanation for activation of the intrinsic apoptotic pathway. These results fit with the hypothesis that deregulated MYC leads to oncogenic stress and DNA-damage, although whether this is direct or indirect remains to be seen.

With regard to events downstream of the DDR, we found an increase in expression of genes associated with activation of mitochondrial outer membrane permeabilisation in pancreatic $\beta$-cells. These included the p53-target $B a x$, and the pro-apoptotic mitochondrial factors Cycs and Endog, which may indicate replenishment of proteins lost from the mitochondria during apoptotic signalling. In addition, increased expression of the tumour suppressor Cdkn2a (p19 ${ }^{\mathrm{Arf}}$ ) was also detected, which may have been involved in stabilization of the p53 tumour suppressor by inhibition of Mdm2, or in promoting cell cycle arrest prior to apoptosis together with up-regulation of the p53-target gene Cdkn1a $\left(\mathrm{p} 21^{\mathrm{Cip} 1}\right)$. In contrast, SBK showed no change in these genes, but instead a decrease in expression of the proapoptotic Bcl2 family member Pmaip1 (Noxa) and the inhibitor of growth gene Ing3 (p47 ${ }^{\text {Ing3 }}$ ). Previous work has linked over-expression of $\mathrm{p} 47^{\text {Ing3 }}$ with apoptosis [76], and reduced expression with human head and neck squamous carcinomas [77]. SBK may be protected from apoptosis in vivo by the Igf1-Akt survival pathway. Of particular interest was the early induction of Igf 1 , $A k t 1$ and $A k t 2$ in the SBK, and the tight correlation seen between the three. Expression of these three genes is also seen at later time points in the pancreas, indicating that the Igf1-Akt pathway may be activated in both tissues but is somehow bypassed in the $\beta$-cells.

One key difference between the two systems appears to be the presence of members of the Kallikrein serine protease family, which were dramatically up-regulated throughout the time-course for SBK. Kallikrein proteins have been linked to many forms of cancer, and of particular note is their role in the Igf1-Akt survival pathway. Klk1, Klk21, Klk24 and Klk27 have been linked to Igf1regulated tumour survival through degradation of the Igf binding protein Igfbp 3 in humans. This prevents Igfbp3 from antagonizing Igf1-Igf1r interactions, allowing Igf1 to bind to its receptor and initiate survival via the Akt pathway [102-104,108]. Interestingly, the highest expression in a similar study from Frye et al. using a basal keratinocyte model for MYC activation [90] was for the brain and skin protease gene Bssp1, also known as Kallikrein 6 (Klk6). This gene remained low in WT treated mice, but was significantly increased following MYC expression (129-fold up-regulated). In both models, MYC activation drives vastly increased Kallikrein expression, so it is possible that these proteins play similar roles in cell survival in both systems. Increased expression of Kallikrein genes in SBK following MYC activation may therefore create an environment that favours survival over apoptosis.

In addition to the increased cell proliferation in both tissues, our data indicate a loss of differentiation in both pancreatic $\beta$-cells and SBK in response to activation of MYC. In pancreatic $\beta$-cells, we found down-regulation of genes that are essential in pancreatic development, such as $P d x 1$ and $N k x 6.1$, as well as genes involved in glucosesensing such as $S l c 2 a 2$ (Glut2) and Gck, both putative MYC-targets. In SBK, many significant changes were detected for genes relating to keratinocyte differentiation that generally pointed to a loss or delay in differentiation - an observation that was previously noted in this mouse model [28]. Interestingly, activation of MYC in the basal layer of the epidermis actually promotes keratinocyte differentiation [93], a mechanism which is thought to prevent epidermal stem cells from becoming cancerous. One possible explanation for the contrasting behaviour in suprabasal epidermis, is that SBKs are post-mitotic and have already entered a terminal differentiation process. Subsequent activation of MYC in early SBK may promote loss of differentiation to enable cell cycle entry. Since MYC-activated SBKs are already migrating upwards towards the skin surface, they are less likely to pose a cancer risk to the host given that they will ultimately be sloughed off as previously shown [28].

We have previously shown that MYC activation in SBK results in a prominent angiogenic phenotype [28]. From our microarray data, potential candidates that may 
promote such a response include $P g f$, a member of the VEGF family, which was highly up-regulated in skin but in fact down-regulated in pancreas. We also found Vegfa up-regulated in skin but not in pancreas. Interestingly Vegfc, which is important in growth of lymphatic vessels, was down-regulated in skin but up-regulated in pancreas. However, given that prominent angiogenesis is not detected in the skin until 3-4 days following MYC activation [28], it is possible that the short time course considered here is too early to identify a transcriptional response in all relevant genes relating to vascularisation. Kallikrein proteins have also been implicated in facilitating angiogenesis via degradation of the cellular matrix [109] and our data showed co-regulation of Pgf and Kallikrein genes. These data suggest that the local tissue microenvironment in SBK that promote angiogenic growth may be linked to survival pathways that protect the cells against apoptosis.

In summary, activation of MYC results in cell growth, loss of differentiation and cell cycle entry in both $\beta$-cells and SBK in vivo. Apoptosis, which is confined to $\beta$-cells, involves a combination of a DNA-damage response and downstream activation of pro-apoptotic signalling pathways, including Cdc2a and p19 Arf $/ \mathrm{p} 53$, and downstream targets. Conversely, avoidance of apoptosis in SBK may result primarily from the activation of key anti-apoptotic signalling pathways, particularly those involved in the Igf1-Akt pathway, and induction of an angiogenic response (Pgf, Vegfa and $K l k s)$. A contributory role for intrinsic resistance to the induction of DNA-damage and the $\mathrm{p} 19^{\mathrm{Arf}}$ tumour suppressor pathway by MYC in SBK is also possible. A possible mechanism whereby tissue-specific environmental factors may influence cell fate following MYC deregulation has also been proposed, hypothesising that the decision to live or die may relate to the local tissue-specific microenvironment. However, this remains speculation as the approach taken here gives an insight into only one aspect of the changes occurring within the cell in response to MYC deregulation. Much remains to be learnt from analysis of protein-level changes, post-translational modifications, or epigenetic modifications of DNA. This study has identified several new lines of investigation for future analysis into the dual roles of MYC in apoptosis and survival. It is hoped that such studies will prove fruitful and provide further insight into the complex role of this enigmatic protein.

\section{Methods}

\section{Tissue Sample Preparation}

Transgenic mice expressing switchable pIns-MYC$\mathrm{ER}^{\mathrm{TAM}}$ in pancreatic $\beta$-cells or inv-MYC-ER ${ }^{\mathrm{TAM}}$ in SBK have been previously characterized and described [27,28]. 8-12 week old male mice were treated with
$4 \mathrm{OHT}$ or vehicle for $4,8,16$ or 32 hours. Triplicate samples were collected for each time point for each of the four conditions; pIns-MYC-ER ${ }^{\text {TAM }} 4 \mathrm{OHT}$ treated/ MYC-ER ${ }^{\text {TAM }}$ active ("Panc T"), pIns-MYC-ER ${ }^{\text {TAM }}$ vehicle treated/MYC inactive ("Panc U"), Inv-MYC-ER ${ }^{\text {TAM }}$ $4 \mathrm{OHT}$ treated/MYC active ("Skin T"), Inv-MYC-ER ${ }^{\text {TAM }}$ vehicle treated/MYC inactive ("Skin U"). All mice were housed and treated in accordance with protocols and regulations sanctioned by the Home Office under the Animals Act of 1986.

\section{RNA Isolation and Microarray Hybridization}

A modified LCM protocol was devised to preserve RNA integrity. Fresh frozen pancreas sections were cut to a thickness of $15 \mu \mathrm{m}$, bound to a MMI MembraneSlide (Molecular Machines and Industries, Rockledge, FL) and fixed in ice-cold $100 \%$ ethanol for 2 mins. Sections were stained briefly (10 secs) with a $1 \%$ Toluidine Blue dye in $100 \%$. Stained sections were dehydrated in 2 changes of $100 \%$ ethanol and 2 changes of xylene for 1 minute each, airdried for 2 minutes and finally left in a vacuum dessicator for 5 minutes before transportation to the laser capture platform. The SL $\mu$ Cut LCM system (Molecular Machines and Industries, Rockledge, FL) was used to isolate islets of Langerhans from surrounding exocrine tissue. RNA was collected using the RNA Microkit protocol (Qiagen, Valencia, CA). The laser capture procedure was repeated on freshly cut pancreas sections to collect a total area of islet cells equal to roughly $1.5 \times 10^{6} \mu^{2}$ for each sample. Due to the thinness of murine suprabasal epidermis, isolation of sufficient good quality RNA for microarray hybridization from LCM of SBK proved difficult, a problem also noted by Agar et al. [110]. RNA was instead collected from 5 fresh frozen skin sections $(20 \mu \mathrm{m})$ collected across several levels of the tissue. A modified version of the Affymetrix GeneChip 2-cycle target labelling in vitro transcription (IVT) protocol was used, incorporating double volumes of polyA controls and reagents in the first round cRNA synthesis stage to increase the yield. $10 \mu \mathrm{g}$ double-amplified biotin-labelled cRNA were hybridized to Affymetrix MOE430 2.0 GeneChips (Affymetrix, Santa Clara, CA) as described in the Affymetrix GeneChip Expression Analysis Technical Manual.

\section{Data Analysis}

Data were normalized across all samples at the probelevel using GC-RMA [111]. Analysis of gene expression data was performed using the Bioconductor microarray analysis packages in R [112] and GeneSpring GX 7.3.1 (Agilent, Santa Clara, CA). 4OHT-treated samples were normalized to their respective vehicle-treated counterparts to ensure that normalized values corresponded to the fold-change in gene expression due to activation of 
MYC-ER ${ }^{\mathrm{TAM}}$. Removal of control and non-responsive probes identified 12,349 probe sets. The custom $\mathrm{R}$ package Envisage was used to identify probe-sets showing significant differential expression after MYC-ER ${ }^{\text {TAM }}$ activation, across time, and between pancreas and skin tissue. p-values were calculated for each model term and their interactions, and were corrected for multiple testing [113]. Only the highest-order interaction p-value was considered for genes where the selected model contains multiple terms relating to the MYC-ER ${ }^{\text {TAM }}$ activation state. Contrast p-values were calculated for each condition by applying an unpaired t-test comparing 4OHT-treated samples with vehicle-treated samples within each of the 8 groups ( 4 hrs, 8 hrs, 16 hrs and 32 hrs for skin or pancreas). Significant early-changing $(\geq$ 2 -fold within 8 hours) probe sets were compared with known gene-ontologies using the DAVID functional annotation tool [29]. Quality threshold (QT) partitional clustering [114] was used to identify genes showing similar expression profiles, using the Pearson cross-correlation coefficient with a minimum correlation of 0.9 and a minimum cluster size of 14 .

\section{Quantitative Real-Time reverse transcriptase PCR}

TaqMan qRT-PCR was performed on original total RNA samples for genes of interest. $20 \mathrm{ng}$ total RNA was reverse transcribed to cDNA using a high-capacity cDNA reverse transcription kit (Applied Biosystems, Foster City, CA). cDNA transcripts were pre-amplified prior to the $\mathrm{qRT}-\mathrm{PCR}$ reaction in a multiplexed reaction using TaqMan preAmp mastermix (Applied Biosystems, Foster City, CA), with pooled TaqMan qRT-PCR assays (Applied Biosystems, Foster City, CA) at a concentration of $0.2 \mathrm{X}$ in $1 \mathrm{X}$ TE buffer. qRT-PCR was performed using an ABI Prism 7000 scanner (Applied Biosystems, Foster City, CA), with an 18s rRNA endogenous control probe (Applied Biosystems, Foster City, CA). qRT-PCR was performed for skin and pancreas $4 \mathrm{OHT}$ - and vehicletreated RNA samples for early time-points 4 hrs and 8 hrs, and for the later 32 hrs time-point. As with microarray analysis, quantitative measures of gene expression upon MYC-activation were calculated by comparing vehicle- and 4OHT-treated samples directly for each condition.

\section{Immunohistochemical Staining}

Frozen sections were cut to $10 \mu \mathrm{m}$ and fixed with $4 \%$ paraformaldehyde (PFA) at room temperature (RT) for 10 mins, washed in PBS for 5 mins, and incubated at $\mathrm{RT}$ in a humidifying temperature for $30 \mathrm{mins}$ in $10 \%$ bovine serum albumin (BSA). Pancreas sections were double stained for Ki67 and insulin, or caspase 3 and insulin. Sections were incubated at $4^{\circ} \mathrm{C}$ overnight in primary antibodies diluted in 1\% BSA: Insulin, 1:100 (guinea pig; DAKO, Denmark); Ki67, 1:200, (rabbit; Novocastra, UK); Caspase 3, 1:200 (rabbit; Cell Signalling Technology Inc., MA). Sections were washed twice in phosphate-buffered saline (PBS) with $0.1 \%$ tween (PBSt) for 5 mins each and incubated for $30 \mathrm{mins}$ at RT in a humidifying chamber with secondary antibodies FITC (Vektor Co., Germany) or ALEXA633 (Invitrogen, Carlsbad, CA) diluted in 1\% BSA (1:200). Skin tissue sections were sequentially stained for Keratin 1 and Ki67, or Keratin 1 and Caspase 3. Sections were incubated for 1 hour in Ki67 or Caspase 3 primary antibodies diluted in $1 \%$ BSA $(1: 200)$. Sections were washed twice with PBSt for 5 mins each and incubated for 30 mins at RT in a humidifying chamber with FITC antirabbit secondary antibodies diluted in 1\% BSA (1:200). Finally, samples were washed in two changes of PBSt for 5 mins each. This cycle was repeated using Keratin 1 primary antibodies (rabbit; BabCo, CA) diluted in 1\% BSA (1:100) and ALEXA633 anti-rabbit secondary antibodies diluted in 1\% BSA (1:200). Slides were mounted in Vectashield (Vector Labs, Burlingame, CA) mounting medium containing 4',6-diamidino-2-phenylindole (DAPI) and viewed using a Leica Sp2 confocal microscope (Leica, Wetzlar, Germany).

\section{Additional material}

Additional file 1: Supplementary gene expression tables and gene set enrichment analysis results

\section{List of abbreviations}

4OHT: 4-Hydroxytamoxifen; 2a-cRNA: Double-amplified biotin-labelled complementary RNA; ANOVA: Analysis of Variance; BSA: Bovine Serum Albumin; CDK: Cyclin-Dependent Kinase; CDKI: Cyclin-Dependent Kinase Inhibitor; ChIP: Chromatin Immunoprecipitation; CRNA: Complementary RNA; DAPI: 4',6-diamidino-2-phenylindole; DNA: Deoxyribonucleic Acid; DPX: Distyrene/Plasticizer/Xylene; ECM: Extra Cellular Matrix; FDR: False Discovery Rate; FWER: Family Wise Error Rate; GCOS: Genechip Operating System; GCRMA: Genechip Robust Multi-array Average; GO: Gene Ontology; IVT: In-Vitro Transcription; LCM: Laser Capture Microdissection; MCM: Minichromosome Maintenance; MMP: Matrix Metalloproteinase; OCT: Optimal Cutting Temperature; PBS: Phosphate Buffered Saline; PFA: Paraformaldehyde; QC: Quality Control; qRT-PCR: Quantitative Real-Time Reverse Transcriptase Polymerase Chain Reaction; RIN: RNA Integrity Number; RM: RIP7-BCl XL/plnsMYC-ER ${ }^{\text {TAM }}$; RNA: Ribonucleic Acide; RT: Room Temperature; SAGE: Serial Analysis of Gene Expression; SBK: Skin Basal Keratinocytes; VEGF: Vascular Endothelial Growth Factor

\section{Acknowledgements}

The authors wish to thank Giorgia Riboldi-Tunnicliffe of Affymetrix UK Ltd. for her assistance with sample preparation optimisation, Geoff Scopes of Affymetrix UK Ltd. for his assistance with array quality control procedures, and Jane Hadlington and Helen Bottomley of Applied Biosystems Ltd. for their assistance with qRT-PCR optimisation. Funding for this project was jointly provided by the EPSRC, BBSRC, AICR, Wellcome Trust, Eli Lilly \& Co. Ltd., and Amylin Pharmaceuticals, Inc.

\section{Author details}

"Wellcome Trust/Cancer Research UK Gurdon Institute, Cambridge, CB2 1QN, UK. ${ }^{2}$ Molecular Biology Service, University of Warwick, CV4 7AL, UK. ${ }^{3}$ Pfizer 
Global R \& D, Kent, CT13 9NJ, UK. ${ }^{4}$ Genstruct Inc, One Alewife Center, Cambridge, MA, 02140, USA. ${ }^{5}$ Warwick Medical School, University of Warwick, CV4 7AL, UK. ${ }^{6}$ Biomedical Research Institute, Department of Biological Sciences, University of Warwick, CV4 7AL, UK.

\section{Authors' contributions}

SR conducted the major part of this study, including designing the experiment, preparing samples, developing the Envisage tools, running all statistical analyses, performing GRT-PCR and immunohistochemical staining, and drafting the manuscript. LW performed all microarray hybridisations. HB assisted with experiment design, microarray hybridisation and manuscript preparation. HT and EH assisted with development of Envisage and other statistical analyses. SP and MK conceived of the study, coordinated the study design, and helped to finalise the manuscript. All authors read and approved the final manuscript.

Data Access

The microarray data described in this experiment are available from the ArrayExpress repository (http://www.ebi.ac.uk/arrayexpress/) with accession number E-MEXP-2952. Envisage code is available upon request.

\section{Competing interests}

At the time this work was carried out, EH was Senior Scientist in Bioinformatics (EMEA) for Agilent Technologies, the developers of the GeneSpring GX analysis suite. The remaining authors declare that they have no competing interests.

Received: 24 March 2011 Accepted: 30 September 2011 Published: 30 September 2011

\section{References}

1. Amati B, Alevizopoulos K, Vlach J: Myc and the cell cycle. Front Biosci 1998, 3:d250-268.

2. Dang CV: C-Myc target genes involved in cell growth, apoptosis, and metabolism. Mol Cell Biol 1999, 19(1):1-11.

3. Coller HA, Grandori C, Tamayo P, Colbert T, Lander ES, Eisenman RN, Golub TR: Expression analysis with oligonucleotide microarrays reveals that MYC regulates genes involved in growth, cell cycle, signaling, and adhesion. Proc Natl Acad Sci USA 2000, 97(7):3260-3265.

4. de Alboran IM, O'Hagan RC, Gartner F, Malynn B, Davidson L, Rickert R, Rajewsky K, DePinho RA, Alt FW: Analysis of C-MYC function in normal cells via conditional gene-targeted mutation. Immunity 2001, 14(1):45-55.

5. Eisenman RN: Deconstructing myc. Genes Dev 2001, 15(16):2023-2030

6. Trumpp A, Refaeli Y, Oskarsson T, Gasser S, Murphy M, Martin GR, Bishop JM: c-Myc regulates mammalian body size by controlling cell number but not cell size. Nature 2001, 414(6865):768-773.

7. Pelengaris S, Khan M, Evan G: c-MYC: more than just a matter of life and death. Nat Rev Cancer 2002, 2(10):764-776.

8. Pelengaris $\mathrm{S}$, Khan M: The many faces of c-MYC. Arch Biochem Biophys 2003, 416(2):129-136

9. Persson H, Hennighausen L, Taub R, DeGrado W, Leder P: Antibodies to human c-myc oncogene product: evidence of an evolutionarily conserved protein induced during cell proliferation. Science 1984, 225(4663):687-693

10. Henriksson M, Luscher B: Proteins of the Myc network: essential regulators of cell growth and differentiation. Adv Cancer Res 1996 68:109-182.

11. Freytag SO: Enforced expression of the c-myc oncogene inhibits cell differentiation by precluding entry into a distinct predifferentiation state in G0/G1. Mol Cell Biol 1988, 8(4):1614-1624

12. Hoffman-Liebermann B, Liebermann DA: Interleukin-6- and leukemia inhibitory factor-induced terminal differentiation of myeloid leukemia cells is blocked at an intermediate stage by constitutive c-myc. Mol Cell Biol 1991, 11(5):2375-2381.

13. Selvakumaran M, Liebermann D, Hoffman-Liebermann B: Myeloblastic leukemia cells conditionally blocked by myc-estrogen receptor chimeric transgenes for terminal differentiation coupled to growth arrest and apoptosis. Blood 1993, 81(9):2257-2262.

14. Wagner AJ, Kokontis JM, Hay N: Myc-mediated apoptosis requires wildtype p53 in a manner independent of cell cycle arrest and the ability of p53 to induce p21waf1/cip1. Genes Dev 1994, 8(23):2817-2830.
15. Tanaka H, Matsumura I, Ezoe S, Satoh Y, Sakamaki T, Albanese C, Machii T, Pestell RG, Kanakura Y: E2F1 and c-Myc potentiate apoptosis through inhibition of NF-kappaB activity that facilitates MnSOD-mediated ROS elimination. Mol Cell 2002, 9(5):1017-1029.

16. Vafa O, Wade M, Kern S, Beeche M, Pandita TK, Hampton GM, Wahl GM: cMyc can induce DNA-damage, increase reactive oxygen species, and mitigate $\mathrm{p} 53$ function: a mechanism for oncogene-induced genetic instability. Mol Cell 2002, 9(5):1031-1044.

17. Alarcon RM, Rupnow BA, Graeber TG, Knox SJ, Giaccia AJ: Modulation of cMyc activity and apoptosis in vivo. Cancer Res 1996, 56(19):4315-4319.

18. Campaner S, Doni M, Hydbring P, Verrecchia A, Bianchi L, Sardella D, Schleker T, Perna D, Tronnersjo S, Murga M, et al: Cdk2 suppresses cellular senescence induced by the c-myc oncogene. Nat Cell Biol 2010, 12(1):54-59, sup pp 51-14.

19. van Riggelen J, Felsher DW: Myc and a Cdk2 senescence switch. Nat Cell Biol 2010, 12(1):7-9.

20. Soucek L, Evan Gl: The ups and downs of Myc biology. Curr Opin Genet Dev 2010, 20(1):91-95.

21. Harrington EA, Fanidi A, Evan Gl: Oncogenes and cell death. Curr Opin Genet Dev 1994, 4(1):120-129.

22. Zeller KI, Jegga AG, Aronow BJ, O'Donnell KA, Dang CV: An integrated database of genes responsive to the Myc oncogenic transcription factor: identification of direct genomic targets. Genome Biol 2003, 4(10):R69.

23. Cheung L, Zervou S, Mattsson G, Abouna S, Zhou L, Ifandi V, Pelengaris S, Khan M: c-Myc directly induces both impaired insulin secretion and loss of $\beta$-cell mass, independently of hyperglycemia in vivo. Islets 2010, 2(1):37-45.

24. Menssen A, Hermeking H: Characterization of the C-MYC-regulated transcriptome by SAGE: identification and analysis of C-MYC target genes. Proc Natl Acad Sci USA 2002, 99(9):6274-6279.

25. Lewis BC, Shim H, Li Q, Wu CS, Lee LA, Maity A, Dang CV: Identification of putative c-Myc-responsive genes: characterization of rcl, a novel growthrelated gene. Mol Cell Biol 1997, 17(9):4967-4978.

26. Patel JH, Loboda AP, Showe MK, Showe LC, McMahon SB: Analysis of genomic targets reveals complex functions of MYC. Nat Rev Cancer 2004, 4(7):562-568.

27. Pelengaris S, Khan M, Evan Gl: Suppression of Myc-induced apoptosis in beta cells exposes multiple oncogenic properties of Myc and triggers carcinogenic progression. Cell 2002, 109(3):321-334.

28. Pelengaris S, Littlewood T, Khan M, Elia G, Evan G: Reversible activation of c-Myc in skin: induction of a complex neoplastic phenotype by a single oncogenic lesion. Mol Cell 1999, 3(5):565-577.

29. Dennis G Jr, Sherman BT, Hosack DA, Yang J, Gao W, Lane HC, Lempicki RA DAVID: Database for Annotation, Visualization, and Integrated Discovery. Genome Biol 2003, 4(5):P3.

30. van Riggelen J, Yetil A, Felsher DW: MYC as a regulator of ribosome biogenesis and protein synthesis. Nat Rev Cancer 2010, 10(4):301-309.

31. Finch A, Prescott J, Shchors K, Hunt A, Soucek L, Dansen TB, Swigart LB, Evan Gl: Bcl-xL gain of function and p19 ARF loss of function cooperate oncogenically with Myc in vivo by distinct mechanisms. Cancer Cell 2006, 10(2):113-120.

32. Subramanian A, Tamayo P, Mootha VK, Mukherjee S, Ebert BL, Gillette MA, Paulovich A, Pomeroy SL, Golub TR, Lander ES, et al: Gene set enrichment analysis: a knowledge-based approach for interpreting genome-wide expression profiles. Proc Natl Acad Sci USA 2005, 102(43):15545-15550.

33. Bild AH, Yao G, Chang JT, Wang Q, Potti A, Chasse D, Joshi MB, Harpole D, Lancaster JM, Berchuck A, et al: Oncogenic pathway signatures in human cancers as a guide to targeted therapies. Nature 2006, 439(7074):353-357.

34. Lee JS, Chu IS, Mikaelyan A, Calvisi DF, Heo J, Reddy JK, Thorgeirsson SS: Application of comparative functional genomics to identify best-fit mouse models to study human cancer. Nat Genet 2004, 36(12):1306-1311.

35. Schuhmacher M, Kohlhuber F, Holzel M, Kaiser C, Burtscher H, Jarsch M, Bornkamm GW, Laux G, Polack A, Weidle UH, et al: The transcriptional program of a human B cell line in response to Myc. Nucleic Acids Res 2001, 29(2):397-406.

36. Yu Q, He M, Lee NH, Liu ET: Identification of Myc-mediated death response pathways by microarray analysis. J Biol Chem 2002, 277(15):13059-13066.

37. Eilers M: Control of cell proliferation by Myc family genes. Mol Cells 1999, $9(1): 1-6$ 
38. Flores I, Murphy DJ, Swigart LB, Knies U, Evan Gl: Defining the temporal requirements for Myc in the progression and maintenance of skin neoplasia. Oncogene 2004, 23(35):5923-5930.

39. Felsher DW, Zetterberg A, Zhu J, Tlsty T, Bishop JM: Over-expression of MYC causes p53-dependent G2 arrest of normal fibroblasts. Proc Natl Acad Sci USA 2000, 97(19):10544-10548.

40. Jansen-Durr P, Meichle A, Steiner P, Pagano M, Finke K, Botz J, Wessbecher J, Draetta G, Eilers M: Differential modulation of cyclin gene expression by MYC. Proc Natl Acad Sci USA 1993, 90(8):3685-3689.

41. Philipp A, Schneider A, Vasrik I, Finke K, Xiong Y, Beach D, Alitalo K, Eilers M: Repression of cyclin D1: a novel function of MYC. Mol Cell Biol 1994 14(6):4032-4043

42. Guo QM, Malek RL, Kim S, Chiao C, He M, Ruffy M, Sanka K, Lee NH, Dang CV, Liu ET: Identification of c-myc responsive genes using rat CDNA microarray. Cancer Res 2000, 60(21):5922-5928.

43. Yin XY, Grove L, Datta NS, Katula K, Long MW, Prochownik EV: Inverse regulation of cyclin B1 by c-Myc and p53 and induction of tetraploidy by cyclin B1 over-expression. Cancer Res 2001, 61(17):6487-6493.

44. Bouchard C, Thieke K, Maier A, Saffrich R, Hanley-Hyde J, Ansorge W, Reed S, Sicinski P, Bartek J, Eilers M: Direct induction of cyclin D2 by Myc contributes to cell cycle progression and sequestration of p27. Embo $J$ 1999, 18(19):5321-5333.

45. Perez-Roger I, Kim SH, Griffiths B, Sewing A, Land H: Cyclins D1 and D2 mediate myc-induced proliferation via sequestration of p27(Kip1) and p21(Cip1). Embo J 1999, 18(19):5310-5320.

46. Bouchard C, Dittrich O, Kiermaier A, Dohmann K, Menkel A, Eilers M, Luscher B: Regulation of cyclin D2 gene expression by the Myc/Max/Mad network: Myc-dependent TRRAP recruitment and histone acetylation at the cyclin D2 promoter. Genes Dev 2001, 15(16):2042-2047.

47. Hermeking H, Rago C, Schuhmacher M, Li Q, Barrett JF, Obaya AJ, O'Connell BC, Mateyak MK, Tam W, Kohlhuber F, et al: Identification of CDK4 as a target of c-MYC. Proc Natl Acad Sci USA 2000, 97(5):2229-2234.

48. Yang W, Shen J, Wu M, Arsura M, FitzGerald M, Suldan Z, Kim DW, Hofmann CS, Pianetti S, Romieu-Mourez R, et al: Repression of transcription of the p27(Kip1) cyclin-dependent kinase inhibitor gene by c-Myc. Oncogene 2001, 20(14):1688-1702.

49. Th'ng JP, Wright PS, Hamaguchi J, Lee MG, Norbury CJ, Nurse P Bradbury EM: The FT210 cell line is a mouse G2 phase mutant with a temperature-sensitive CDC2 gene product. Cell 1990, 63(2):313-324.

50. Itzhaki JE, Gilbert CS, Porter AC: Construction by gene targeting in human cells of a "conditional' CDC2 mutant that rereplicates its DNA. Nat Genet 1997, 15(3):258-265.

51. Santamaria D, Barriere C, Cerqueira A, Hunt S, Tardy C, Newton K, Caceres JF, Dubus P, Malumbres M, Barbacid M: Cdk1 is sufficient to drive the mammalian cell cycle. Nature 2007, 448(7155):811-815.

52. Kaldis P, Aleem E: Cell cycle sibling rivalry: Cdc2 vs. Cdk2. Cell Cycle 2005, 4(11):1491-1494

53. Castedo M, Perfettini JL, Roumier T, Kroemer G: Cyclin-dependent kinase-1: linking apoptosis to cell cycle and mitotic catastrophe. Cell Death Differ 2002, 9(12):1287-1293

54. Serrano M, Hannon GJ, Beach D: A new regulatory motif in cell-cycle control causing specific inhibition of cyclin D/CDK4. Nature 1993, 366(6456):704-707.

55. Guan KL, Jenkins CW, Li Y, Nichols MA, Wu X, O'Keefe CL, Matera AG, Xiong Y: Growth suppression by p18, a p16INK4/MTS1- and p14INK4B/ MTS2-related CDK6 inhibitor, correlates with wild-type pRb function. Genes Dev 1994, 8(24):2939-2952

56. Goruppi S, Ruaro E, Schneider C: Gas6, the ligand of Axl tyrosine kinase receptor, has mitogenic and survival activities for serum starved $\mathrm{NIH} 3 \mathrm{T3}$ fibroblasts. Oncogene 1996, 12(3):471-480.

57. Li R, Chen J, Hammonds G, Phillips H, Armanini M, Wood P, Bunge R, Godowski PJ, Sliwkowski MX, Mather JP: Identification of Gas6 as a growth factor for human Schwann cells. J Neurosci 1996, 16(6):2012-2019.

58. Ganopolsky JG, Abid MR, Aird WC, Blostein MD: GAS6-induced signaling in human endothelial cells is mediated by FOXO1a. J Thromb Haemost 2008, 6(10):1804-1811.

59. Shankar SL, O'Guin K, Cammer M, McMorris FA, Stitt TN, Basch RS, Varnum B, Shafit-Zagardo B: The growth arrest-specific gene product Gas6 promotes the survival of human oligodendrocytes via a phosphatidylinositol 3-kinase-dependent pathway. J Neurosci 2003, 23(10):4208-4218.
60. Watson JD, Oster SK, Shago M, Khosravi F, Penn LZ: Identifying genes regulated in a Myc-dependent manner. J Biol Chem 2002, 277(40):36921-36930.

61. Jensen KB, Watt FM: Single-cell expression profiling of human epidermal stem and transit-amplifying cells: Lrig1 is a regulator of stem cell quiescence. Proc Natl Acad Sci USA 2006, 103(32):11958-11963.

62. Zindy F, Eischen CM, Randle DH, Kamijo T, Cleveland JL, Sherr CJ, Roussel MF: Myc signaling via the ARF tumor suppressor regulates p53dependent apoptosis and immortalization. Genes Dev 1998, 12(15):2424-2433.

63. Eischen CM, Weber JD, Roussel MF, Sherr CJ, Cleveland JL: Disruption of the ARF-Mdm2-p53 tumor suppressor pathway in Myc-induced lymphomagenesis. Genes Dev 1999, 13(20):2658-2669.

64. Murphy DJ, Junttila MR, Pouyet L, Karnezis A, Shchors K, Bui DA, BrownSwigart L, Johnson L, Evan Gl: Distinct thresholds govern Myc's biological output in vivo. Cancer Cell 2008, 14(6):447-457.

65. Halgren RG, Fielden MR, Fong CJ, Zacharewski TR: Assessment of clone identity and sequence fidelity for 1189 IMAGE cDNA clones. Nucleic Acids Res 2001, 29(2):582-588.

66. Dansen TB, Whitfield J, Rostker F, Brown-Swigart L, Evan GI: Specific requirement for Bax, not Bak, in Myc-induced apoptosis and tumor suppression in vivo. J Biol Chem 2006, 281(16):10890-10895.

67. Mitchell KO, Ricci MS, Miyashita T, Dicker DT, Jin Z, Reed JC, El-Deiry WS: Bax is a transcriptional target and mediator of c-myc-induced apoptosis. Cancer Res 2000, 60(22):6318-6325.

68. Fernandez PC, Frank SR, Wang L, Schroeder M, Liu S, Greene J, Cocito A, Amati B: Genomic targets of the human c-Myc protein. Genes Dev 2003, 17(9):1115-1129.

69. Morrish F, Giedt C, Hockenbery D: C-MYC apoptotic function is mediated by NRF-1 target genes. Genes Dev 2003, 17(2):240-255

70. Li Z, Van Calcar S, Qu C, Cavenee WK, Zhang MQ, Ren B: A global transcriptional regulatory role for c-Myc in Burkitt's lymphoma cells. Proc Natl Acad Sci USA 2003, 100(14):8164-8169.

71. Mao DY, Watson JD, Yan PS, Barsyte-Lovejoy D, Khosravi F, Wong WW Farnham PJ, Huang TH, Penn LZ: Analysis of Myc bound loci identified by CpG island arrays shows that Max is essential for Myc-dependent repression. Curr Biol 2003, 13(10):882-886.

72. Maclean KH, Kastan MB, Cleveland JL: Atm deficiency affects both apoptosis and proliferation to augment Myc-induced lymphomagenesis. Mol Cancer Res 2007, 5(7):705-711.

73. Schlosser I, Holzel M, Murnseer M, Burtscher H, Weidle UH, Eick D: A role for $\mathrm{c}-\mathrm{Myc}$ in the regulation of ribosomal RNA processing. Nucleic Acids Res 2003, 31(21):6148-6156.

74. Park BJ, Kang JW, Lee SW, Choi SJ, Shin YK, Ahn YH, Choi YH, Choi D, Lee KS, Kim S: The haploinsufficient tumor suppressor p18 upregulates p53 via interactions with ATM/ATR. Cell 2005, 120(2):209-221.

75. Lowe SW, Cepero E, Evan G: Intrinsic tumour suppression. Nature 2004, 432(7015):307-315

76. Nagashima M, Shiseki M, Pedeux RM, Okamura S, Kitahama-Shiseki M, Miura K, Yokota J, Harris CC: A novel PHD-finger motif protein, p47ING3, modulates p53-mediated transcription, cell cycle control, and apoptosis. Oncogene 2003, 22(3):343-350.

77. Gunduz M, Ouchida M, Fukushima K, Ito S, Jitsumori Y, Nakashima T, Nagai N, Nishizaki K, Shimizu K: Allelic loss and reduced expression of the ING3, a candidate tumor suppressor gene at 7q31, in human head and neck cancers. Oncogene 2002, 21(28):4462-4470.

78. Wiley SR, Cassiano L, Lofton T, Davis-Smith T, Winkles JA, Lindner V, Liu H, Daniel TO, Smith CA, Fanslow WC: A novel TNF receptor family member binds TWEAK and is implicated in angiogenesis. Immunity 2001, 15(5):837-846.

79. Wiley SR, Winkles JA: TWEAK, a member of the TNF superfamily, is a multifunctional cytokine that binds the TweakR/Fn14 receptor. Cytokine Growth Factor Rev 2003, 14(3-4):241-249.

80. Rogers PR, Song J, Gramaglia I, Killeen N, Croft M: OX40 promotes BCl-xL and $\mathrm{BCl}-2$ expression and is essential for long-term survival of CD4 T cells. Immunity 2001, 15(3):445-455.

81. Odorisio T, Schietroma C, Zaccaria ML, Cianfarani F, Tiveron C, Tatangelo L, Failla CM, Zambruno G: Mice overexpressing placenta growth factor exhibit increased vascularization and vessel permeability. J Cell Sci 2002, 115(Pt 12):2559-2567. 
82. Coppola JA, Cole MD: Constitutive c-myc oncogene expression blocks mouse erythroleukaemia cell differentiation but not commitment. Nature 1986, 320(6064):760-763

83. Maruyama K, Schiavi SC, Huse W, Johnson GL, Ruley HE: myc and E1A oncogenes alter the responses of PC12 cells to nerve growth factor and block differentiation. Oncogene 1987, 1(4):361-367.

84. Chakrabarti SK, Mirmira RG: Transcription factors direct the development and function of pancreatic beta cells. Trends Endocrinol Metab 2003, 14(2):78-84

85. Hui H, Perfetti R: Pancreas duodenum homeobox-1 regulates pancreas development during embryogenesis and islet cell function in adulthood. Eur J Endocrinol 2002, 146(2):129-141.

86. Sander M, Sussel L, Conners J, Scheel D, Kalamaras J, Dela Cruz F, Schwitzgebel V, Hayes-Jordan A, German M: Homeobox gene Nkx6.1 lies downstream of Nkx2.2 in the major pathway of beta-cell formation in the pancreas. Development 2000, 127(24):5533-5540.

87. Gu G, Wells JM, Dombkowski D, Preffer F, Aronow B, Melton DA: Global expression analysis of gene regulatory pathways during endocrine pancreatic development. Development 2004, 131(1):165-179.

88. Eckert RL, Green $\mathrm{H}$ : Structure and evolution of the human involucrin gene. Cell 1986, 46(4):583-589.

89. Arnold I, Watt FM: c-Myc activation in transgenic mouse epidermis results in mobilization of stem cells and differentiation of their progeny. Curr Biol 2001, 11(8):558-568.

90. Frye M, Gardner C, Li ER, Arnold I, Watt FM: Evidence that Myc activation depletes the epidermal stem cell compartment by modulating adhesive interactions with the local microenvironment. Development 2003, 130(12):2793-2808

91. Jarvinen M, Rinne A, Hopsu-Havu VK: Human cystatins in normal and diseased tissues-a review. Acta Histochem 1987, 82(1):5-18.

92. Hawley-Nelson P, Roop DR, Cheng CK, Krieg TM, Yuspa SH: Molecular cloning of mouse epidermal cystatin $\mathrm{A}$ and detection of regulated expression in differentiation and tumorigenesis. Mol Carcinog 1988, 1(3):202-211.

93. Berta MA, Baker CM, Cottle DL, Watt FM: Dose and context dependent effects of Myc on epidermal stem cell proliferation and differentiation. EMBO Mol Med 2010, 2(1):16-25.

94. Ishimi Y: A DNA helicase activity is associated with an MCM4, -6 , and -7 protein complex. J Biol Chem 1997, 272(39):24508-24513.

95. Komatsu N, Takata M, Otsuki N, Toyama T, Ohka R, Takehara K, Saijoh K: Expression and localization of tissue kallikrein mRNAs in human epidermis and appendages. J Invest Dermatol 2003, 121(3):542-549.

96. Borgono CA, Diamandis EP: The emerging roles of human tissue kallikreins in cancer. Nat Rev Cancer 2004, 4(11):876-890.

97. Petraki CD, Gregorakis AK, Papanastasiou PA, Karavana VN, Luo LY, Diamandis EP: Immunohistochemical localization of human kallikreins 6, 10 and 13 in benign and malignant prostatic tissues. Prostate Cancer Prostatic Dis 2003, 6(3):223-227.

98. Sano A, Sangai T, Maeda H, Nakamura M, Hasebe T, Ochiai A: Kallikrein 11 expressed in human breast cancer cells releases insulin-like growth factor through degradation of IGFBP-3. Int J Oncol 2007, 30(6):1493-1498.

99. lacobuzio-Donahue CA, Ashfaq R, Maitra A, Adsay NV, Shen-Ong GL, Berg K, Hollingsworth MA, Cameron JL, Yeo CJ, Kern SE, et al: Highly expressed genes in pancreatic ductal adenocarcinomas: a comprehensive characterization and comparison of the transcription profiles obtained from three major technologies. Cancer Res 2003, 63(24):8614-8622.

100. Yousef GM, Yacoub GM, Polymeris ME, Popalis C, Soosaipillai A, Diamandis EP: Kallikrein gene down-regulation in breast cancer. $\mathrm{Br} J$ Cancer 2004, 90(1):167-172.

101. Yousef GM, Kyriakopoulou LG, Scorilas A, Fracchioli S, Ghiringhello B, Zarghooni M, Chang A, Diamandis M, Giardina G, Hartwick WJ, et al: Quantitative expression of the human kallikrein gene 9 (KLK9) in ovarian cancer: a new independent and favorable prognostic marker. Cancer Res 2001, 61(21):7811-7818.

102. Matsui H, Moriyama A, Takahashi T: Cloning and characterization of mouse klk27, a novel tissue kallikrein expressed in testicular Leydig cells and exhibiting chymotrypsin-like specificity. Eur J Biochem 2000 267(23):6858-6865.

103. Matsui H, Takahashi T: Mouse testicular Leydig cells express Klk21, a tissue kallikrein that cleaves fibronectin and IGF-binding protein-3. Endocrinology 2001, 142(11):4918-4929.
104. Matsui H, Takano N, Moriyama A, Takahashi T: Single-chain tissue-type plasminogen activator is a substrate of mouse glandular kallikrein 24. Zoolog Sci 2005, 22(10):1105-1111.

105. Krady MM, Zeng J, Yu J, MacLauchlan S, Skokos EA, Tian W, Bornstein P, Sessa WC, Kyriakides TR: Thrombospondin-2 modulates extracellular matrix remodeling during physiological angiogenesis. Am J Pathol 2008 173(3):879-891.

106. Dominguez-Sola D, Ying CY, Grandori C, Ruggiero L, Chen B, Li M, Galloway DA, Gu W, Gautier J, Dalla-Favera R: Non-transcriptional control of DNA replication by c-Myc. Nature 2007, 448(7152):445-451.

107. Pusapati RV, Rounbehler RJ, Hong S, Powers JT, Yan M, Kiguchi K, McArthur MJ, Wong PK, Johnson DG: ATM promotes apoptosis and suppresses tumorigenesis in response to Myc. Proc Natl Acad Sci USA 2006, 103(5):1446-1451

108. Rehault S, Monget P, Mazerbourg S, Tremblay R, Gutman N, Gauthier F, Moreau T: Insulin-like growth factor binding proteins (IGFBPs) as potential physiological substrates for human kallikreins hK2 and hK3. Eur J Biochem 2001, 268(10):2960-2968.

109. Tschesche H, Michaelis J, Kohnert U, Fedrowitz J, Oberhoff R: Tissue kallikrein effectively activates latent matrix degrading metalloenzymes. Adv Exp Med Biol 1989, 247A:545-548.

110. Agar NS, Halliday GM, Barnetson RS, Jones AM: A novel technique for the examination of skin biopsies by laser capture microdissection. J Cutan Pathol 2003, 30(4):265-270.

111. Wu Z, Irizarry RA, Gentleman R, Murillo FM, Spencer F: A Model Based Background Adjustment for Oligonucleotide Expression Arrays. Johns Hopkins University Department of Biostatistics Working Papers 2004.

112. Gentleman RC, Carey VJ, Bates DM, Bolstad B, Dettling M, Dudoit S, Ellis B, Gautier L, Ge Y, Gentry J, et al: Bioconductor: open software development for computational biology and bioinformatics. Genome Biol 2004, 5(10): R80.

113. Benjamini $Y$, Hochberg $Y$ : Controlling the false discovery rate: a practical and powerful approach to multiple testing. Journal of the Royal Statistical Society 1995, Ser. B 57:289-300.

114. Heyer $L$, Kruglyak S, Yooseph S: Exploring expression data: identification and analysis of coexpressed genes. Genome Res 1999, 9(11):1106-1115.

doi:10.1186/1471-2164-12-476

Cite this article as: Robson et al:: Deciphering c-MYC-regulated genes in two distinct tissues. BMC Genomics 2011 12:476.

\section{Submit your next manuscript to BioMed Central and take full advantage of:}

- Convenient online submission

- Thorough peer review

- No space constraints or color figure charges

- Immediate publication on acceptance

- Inclusion in PubMed, CAS, Scopus and Google Scholar

- Research which is freely available for redistribution 